\title{
Serotonergic Modulation of GABAergic and Glutamatergic Synaptic Transmission in Mechanically Isolated Rat Medial Preoptic Area Neurons
}

\author{
Jong-Ju Lee ${ }^{1,2,3}$, Eu-Teum Hahm ${ }^{1,2,3}$, Choong-Hyun Lee ${ }^{4}$ and Young-Wuk Cho*, I,2,3 \\ 'Department of Physiology, College of Medicine, Kyung Hee University, Seoul, South Korea; ${ }^{2}$ Biomedical Science Institute, Kyung Hee University, \\ Seoul, South Korea; ${ }^{3}$ Medical Research Center for Reactive Oxygen Species, Kyung Hee University, Seoul, South Korea; ${ }^{4}$ Department of Urology, \\ College of Medicine, Kyung Hee University, Seoul, South Korea
}

\begin{abstract}
The medial preoptic area (MPOA) of the hypothalamus is critically involved in the regulation of male sexual behavior and has been implicated in several homeostatic processes. Serotonin (5-hydroxytryptamine, 5-HT) inhibits sexual behavior via effects in the MPOA, where there are high densities of 5- $\mathrm{HT}_{\mathrm{IA}}$ and $5-\mathrm{HT}$ IB receptor subtypes. We used whole-cell recordings under voltage-clamp conditions to investigate the serotonergic modulation of $\gamma$-aminobutyric acid (GABA)ergic and glutamatergic synaptic transmission in mechanically dissociated rat MPOA neurons with native presynaptic nerve endings. Spontaneous GABAergic miniature inhibitory postsynaptic currents (mIPSCs) in the MPOA were completely blocked by bicuculline. Serotonin reversibly reduced the GABAergic mIPSC frequency without affecting the mean current amplitude. Serotonergic inhibition of mIPSC frequency was mimicked by ( \pm )-8-hydroxy-2dipropylaminotetralin hydrobromide, a specific 5-HTIA receptor agonist, and blocked by I-(2-methoxyphenyl)-4-[4-(2-phthalimido)butyl] piperazine hydrobromide, a specific 5-HTIA receptor antagonist. 6-Cyano-7-nitroquinoxaline-2,3-dione completely blocked spontaneous glutamatergic miniature excitatory postsynaptic currents (mEPSCs) in the MPOA. Serotonin reversibly decreased the glutamatergic mEPSC frequency without affecting the mean current amplitude. Serotonergic inhibition of mEPSC frequency was mimicked by CGS 12066B, a specific 5-HT IB receptor agonist, and blocked by SB 21664I, a specific 5-HT IB receptor antagonist. Stimulation of adenylyl cyclase with forskolin increased the frequencies of GABAergic mIPSCs and glutamatergic mEPSCs, and blocked the inhibitory effects of 5-HT. H-89, a selective protein kinase A (PKA) inhibitor, decreased the frequencies of GABAergic mIPSCs and glutamatergic mEPSCs, and blocked their reduction by 5-HT. These findings suggest that 5-HT reduces the frequency of GABAergic mIPSCs and glutamatergic mEPSCs through 5-HTIA and 5-HT 1 B receptor-mediated inhibition, respectively, of the PKA-dependent pathway in the presynaptic nerve terminals of MPOA neurons.

Neuropsychopharmacology (2008) 33, 340-352; doi: I 0. I038/sj.npp. I 30 I 396; published online 28 March 2007
\end{abstract}

Keywords: medial preoptic area; serotonin; synaptic transmission; GABA; glutamate; PKA

\section{INTRODUCTION}

The medial preoptic area (MPOA) of the hypothalamus is critically involved in the regulation of male sexual behavior (Meisel and Sachs, 1994) and has been implicated in several homeostatic processes (Swanson and Mogenson, 1981; van Gemert et al, 1975). Damage to the MPOA impairs sexual behavior (Klaric and Hendricks, 1986; Paredes et al, 1998), whereas stimulation of the MPOA facilitates sexual behavior (Malsbury, 1971; Rodriguez-Manzo et al, 2000). The MPOA exerts its various functions via widespread neuronal

*Correspondence: Dr Y-W Cho, Department of Physiology and Biomedical Science Institute, College of Medicine, Kyung Hee University, Seoul |30-70|, South Korea, Tel: + $82296 \mid 0534$, Fax: + 8250596 I 0534, E-mail: ywcho@khu.ac.kr

Received 23 October 2006; revised I4 February 2007; accepted 15 February 2007 connections in the central nervous system (CNS) (Simerly and Swanson, 1986, 1988). Neuroanatomical investigation of the MPOA demonstrated projections to this region from neurons releasing many putative neurotransmitters and neuromodulators (Simerly et al, 1986), and electrophysiological studies showed that MPOA neurons can generate currents mediated by $\alpha$-amino-3-hydroxy-5-methyl-4-isoxazolepropionic acid (AMPA), $N$-methyl-D-aspartate, $\gamma$-aminobutyric acid $(\mathrm{GABA})_{\mathrm{A}}$, and glycine receptors (Karlsson et al, 1997a,b).

Serotonin (5-hydroxytryptamine, 5-HT), a neurotransmitter and neuromodulator, is widely distributed in the mammalian CNS, where it plays a role in sleep, cognition, sensory perception, motor activity, temperature regulation, appetite, hormone secretion, nociception, and sexual behavior (Jacobs and Azmitia, 1992). The cellular actions of $5-\mathrm{HT}$ are mediated by up to 14 distinct receptor subtypes 
located in the cell membrane (Hoyer and Martin, 1997). Regulation of male sexual behavior by 5-HT has been studied in humans, primates, and rodents. In most cases, pharmacological manipulation of 5-HT has shown an inhibitory effect on sexual motivation and performance (Gorzalka et al, 1990; Hull et al, 2004; Zajecka et al, 1991). Microinjection of 5-HT into the MPOA of male rats has been shown to impair sexual activity (Fernandez-Guasti et al, 1992; Verma et al, 1989). Conversely, decreasing serotonergic activity, by either lesioning the brain or inhibiting 5-HT synthesis, has been shown to facilitate sexual behavior (Hull et al, 2004; Gorzalka et al, 1990).

The brain localization of $5-\mathrm{HT}_{1}$ receptor subtypes is well described. A high density of $5-\mathrm{HT}_{1 \mathrm{~A}}$ receptors is found in the hippocampus, whereas the highest concentrations of $5-\mathrm{HT}_{1 \mathrm{~B}}$ receptors are found in the substantia nigra, globus pallidus, and dorsal subiculum (Pazos and Palacios, 1985). Both receptor subtypes are present at high densities in the MPOA (Pazos and Palacios, 1985), but it is not clear which one mediates the inhibitory effects of serotonin. In addition, electrophysiological studies have revealed that 5-HT suppressed the transmitter release probability in GABAcontaining as well as in glutamate-containing presynaptic nerve terminals on MPOA neurons (Malinina et al, 2005). However, the presynaptic mechanisms of serotonergic inhibition of the GABAergic and glutamatergic synaptic transmission in the MPOA neurons have not yet been elucidated. Thus, the present study investigated the electrophysiological and pharmacological mechanisms for serotonergic inhibition of sexual function by performing conventional whole-cell patch-clamp recordings in mechanically isolated rat MPOA neurons under voltage-clamp conditions.

\section{METHODS}

\section{Preparation}

All experiments conformed to the guiding principles for the care and use of animals approved by the Council of the Korean Physiological Society and the National Institutes of Health Guide for the Care and Use of Laboratory Animals. All efforts were made to minimize the number of animals as well as suffering.

Single MPOA neurons with presynaptic boutons were isolated using techniques described previously (Akaike and Moorhouse, 2003; Hahm et al, 2004). In brief, 10- to 15-dayold Sprague-Dawley rats of both sexes were decapitated under Zoletil $50^{\circledR}$ anesthesia $\left(50 \mathrm{mg} \mathrm{kg}^{-1}\right.$, i.p.). Brains were quickly removed and transversely sliced at a thickness of $400 \mu \mathrm{m}$ using a vibratome (Series 1500 , Vibratome, St Louis, $\mathrm{MO})$. Before mechanical dissection, slices were preincubated for at least $1 \mathrm{~h}$ at room temperature $\left(22-25^{\circ} \mathrm{C}\right)$ in solution well saturated with $95 \% \quad \mathrm{O}_{2}$ and $5 \% \mathrm{CO}_{2}$. For dissociation, slices were transferred to a $35-\mathrm{mm}$ plastic culture dish (Falcon Primaria 3801, Becton Dickinson, Rutherford, NJ), and the MPOA was identified under a binocular microscope (SZ-ST, Olympus, Tokyo, Japan). Mechanical dissociation was accomplished using a custombuilt vibration device and a fire-polished glass pipette oscillating at approximately $50-60 \mathrm{~Hz}$. The tip of the pipette was lightly placed on the surface of the MPOA and vibrated horizontally (0.1-0.2 $\mathrm{mm}$ displacement) for approximately $2 \mathrm{~min}$. Slices were removed, and the mechanically dissociated neurons were allowed to settle and adhere to the bottom of the dish for at least 15 min before commencement of recording. The neurons undergoing dissociation retained short portions of their proximal dendrites.

\section{Electrophysiological Recordings}

Electrophysiological recordings were performed in the conventional whole-cell patch-clamp recording mode (Hamill et al, 1981) under voltage-clamp conditions. Patch pipettes were prepared from glass capillaries (1B150F-4, World Precision Instruments Inc., Sarasota, FL) on a vertical pipette puller (PP-830, Narishige, Tokyo, Japan) in two stages. The patch pipette was positioned on the neuron using a water-driven micromanipulator (WR-60, Narishige, Tokyo, Japan). The resistance between the recording electrode filled with the internal pipette solution and the reference electrode was 5-7 M . The neurons were visualized with phase-contrast equipment on an inverted microscope (IX-70, Olympus, Tokyo, Japan). Electrical stimulation, current recordings, and current filtration (at $1 \mathrm{kHz}$ ) were obtained with an EPC-10 patch-clamp amplifier (HEKA Electronik, Lambrecht, Germany) linked to an IBM-compatible PC controlled by HEKA software. Data were digitized with a LIH 1600 board (HEKA Electronik, Lambrecht, Germany) and stored on a hard disk. The currents were monitored on a thermal linear corder (WR3320-3CL, Graphtec Co., Yokohama, Japan). All experiments were performed at room temperature $\left(22-25^{\circ} \mathrm{C}\right)$.

\section{Data Analysis}

Spontaneous miniature inhibitory and excitatory postsynaptic currents (mIPSCs and mEPSCs) were counted and analyzed using the MiniAnalysis program (Synaptosoft Inc., Leonia, NJ). For curve fitting, Kaleida Graph software (Synergy Software, Reading, PA) was used. To set the adequate threshold for mIPSCs and mEPSCs, we analyzed mIPSCs and mEPSCs at the threshold of $1 \mathrm{pA}$, and then manually accepted or rejected each event according to the characteristics of rise time and decay time kinetics. Then, we plotted the histogram of amplitude distribution of mIPSCs and mEPSCs. Almost all events of mIPSCs and mEPSCs were larger than $10-20$ and 5-10 pA, respectively (Figures $1 \mathrm{c}$ and $5 \mathrm{c}$ ). Thus, we set the threshold for event detection at 10-20 pA for mIPSC and 5-10 pA for mEPSC. Spontaneous events were initially detected automatically using an amplitude threshold of 10-20 pA for the recording of mIPSCs and 5-10 pA for mEPSCs at the holding voltage $\left(V_{\mathrm{H}}\right)$ of $-60 \mathrm{mV}$. After automatic detection, all events were manually accepted or rejected on the basis of the rise and decay times. Events with brief rise times $(0.5-1.5 \mathrm{~ms})$ that were well fitted by a single-exponential function were selected for analysis. The amplitudes and inter-event intervals of large numbers of mIPSCs and mEPSCs obtained from a single neuron were examined by constructing allpoint cumulative probability distributions and compared using the Kolmogorov-Smirnov test with Stat View software (SAS Institute Inc., Cary, NC). Mean amplitudes and 
a

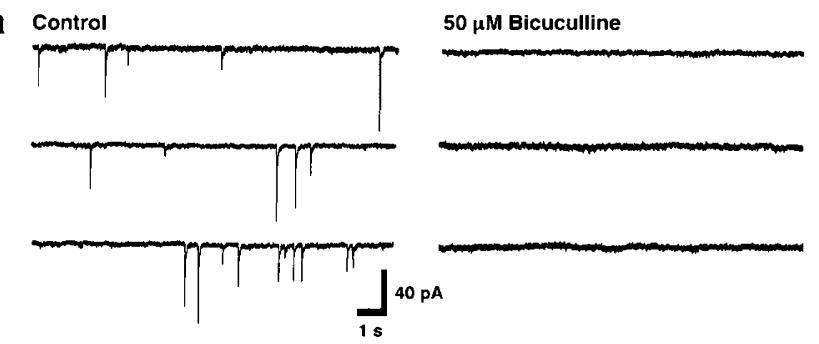

b $\quad\left[\mathrm{Cl}^{-}\right]_{\mathrm{i}}=140 \mathrm{mM} \quad\left[\mathrm{Cl}^{-}\right]_{0}=161 \mathrm{mM}$

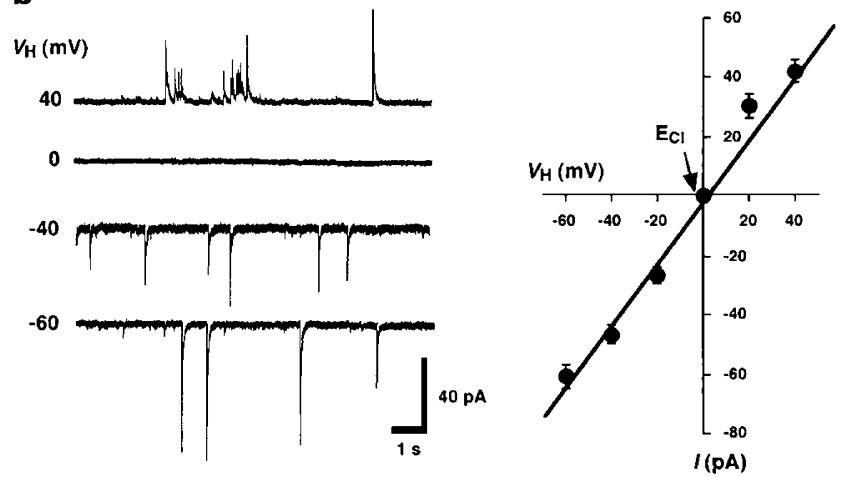

C

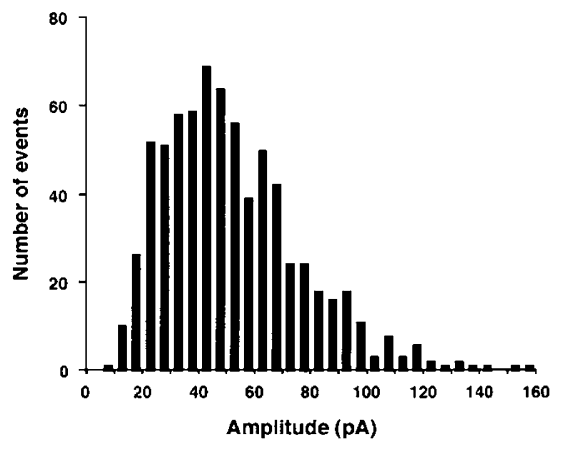

Figure I GABAergic mIPSCs recorded from mechanically dissociated MPOA neurons. (a) In the presence of $300 \mathrm{nM}$ TTX, $3 \mu \mathrm{M}$ CNQX, and I0 $\mu \mathrm{M}$ AP5, superfusion of $50 \mu \mathrm{M}$ bicuculline completely and reversibly blocked mIPSCs in isolated MPOA neurons $\left(V_{H}=-60 \mathrm{mV}\right)$. (b) Traces of mIPSCs recorded at $V_{H}$ of $-60,-40,0$, and $+40 \mathrm{mV}$. Intracellular and extracellular $\mathrm{Cl}^{-}$concentrations were 140 and $16 \mathrm{I} \mathrm{mM}$, respectively. I-V curve for the mean amplitude of mIPSCs recorded at various $V_{H}$ s. Each point is the mean of four neurons. (c) A histogram showing typical amplitude distribution of mIPSCs. The amplitudes of 717 events detected at the threshold of I pA were plotted. Amplitudes of almost all events were larger than $10 \mathrm{pA}$. The bin size was $5 . \mathrm{V}_{\mathrm{H}}=-60 \mathrm{mV}$.

frequencies of mIPSCs and mEPSCs were normalized to the control conditions and are reported as means \pm SEM. Differences in mean amplitude and frequency of mIPSCs and mEPSCs were tested with Student's paired two-tailed $t$-test using absolute rather than normalized values. Values of $P<0.05$ were considered significant.

\section{Solutions}

The ionic composition of the incubation solution was (in $\mathrm{mM}$ ): $\mathrm{NaCl} 124, \mathrm{KCl} 5, \mathrm{KH}_{2} \mathrm{PO}_{4} 1.2, \mathrm{MgSO}_{4} 1.3, \mathrm{CaCl}_{2}$ 2.4, glucose 10, and $\mathrm{NaHCO}_{3} 24$. The $\mathrm{pH}$ was adjusted to 7.4 by continuous bubbling with $95 \% \mathrm{O}_{2}$ and $5 \% \mathrm{CO}_{2}$. The standard external solution was (in $\mathrm{mM}$ ): $\mathrm{NaCl} 150, \mathrm{KCl} 5$, $\mathrm{MgCl}_{2} 1, \mathrm{CaCl}_{2}$ 2, glucose 10 , and $\mathrm{N}$-2-hydroxyethylpiperazine- $N^{\prime}$-2-ethanesulphonic acid (HEPES) 10. The $\mathrm{pH}$ was adjusted to 7.4 with tris-hydroxymethyl aminomethane (Tris-base). The composition of the internal pipette solution for mIPSC recording was (in $\mathrm{mM}$ ): $\mathrm{CsCl} 110$, TEA-Cl 30, ethylene glycol-bis ( $\beta$-aminoethyl ether)- $N, N, N^{\prime} N^{\prime}$-tetraacetic acid (EGTA) 5, adenosine $5^{\prime}$-triphosphate magnesium salt (Mg-ATP) 5, guanosine $5^{\prime}$-triphosphate trisodium salt ( $\mathrm{Na}_{3}$-GTP) 0.4 , and HEPES 10 . The $\mathrm{pH}$ was adjusted to 7.2 with Tris-base. For mIPSC recording, external solutions contained $300 \mathrm{nM}$ TTX, $3 \mu \mathrm{M}$ 6-cyano-7-nitroquinoxaline2,3-dione (CNQX), and $10 \mu \mathrm{M}$ DL-2-amino-5-phosphonovaleric acid (AP5) to block voltage-dependent $\mathrm{Na}^{+}$channels and glutamatergic excitatory synaptic currents. The composition of the internal pipette solution for mEPSC recording was (in $\mathrm{mM}$ ): cesium methanesulfonate 120, TEA-Cl 10, EGTA 5, NaCl 10, Mg-ATP 5, Na-GTP 0.4, and HEPES 10. The $\mathrm{pH}$ was adjusted to 7.2 with Tris-base. For mEPSC recording, external solutions contained $300 \mathrm{nM}$ TTX and $10 \mu \mathrm{M}(-)$-bicuculline methochloride (bicuculline) to block voltage-dependent $\mathrm{Na}^{+}$channels and GABAergic inhibitory synaptic currents.

\section{Drugs and Chemicals}

Zoletil $50^{\circledR}$ (tiletamine $\mathrm{HCl} 125 \mathrm{mg} / 5 \mathrm{ml}+$ zolazepam $\mathrm{HCl}$ $125 \mathrm{mg} / 5 \mathrm{ml})$ was purchased from Virbac laboratory $(06516$ Carros, France). Tetrodotoxin, (-)-bicuculline methochloride, CNQX, AP5, EGTA, Mg-ATP, $\mathrm{Na}_{3}$ GTP, methanesulfonic acid, HEPES, dimethyl sulfoxide, $N$-methyl-D-glucamine, $\mathrm{BaCl}_{2}, \mathrm{CsCl}, \mathrm{CdCl}_{2}$, cesium methanesulfonate, 4-aminopyridine (4-AP), forskolin, $N$-(2-[p-bromocinnamylamino] ethyl)-5-isoquinolinesulfonamide hydrochloride (H89 ), and 5- $\mathrm{HT} \mathrm{HCl}$ were purchased from Sigma (St Louis, MO). ( \pm )-8-Hydroxy-2-dipropylaminotetralin hydrobromide (8-OH-DPAT), $\alpha$-methyl-5-hydroxytryptamine maleate $(\alpha$-methyl-5-HT), 7-trifluoromethyl-4-(4-methyl-1piperazinyl)pyrrolo[1,2-a]-quinoxaline dimaleate (CGS 12066B), NAN-190 hydrobromide, ketanserin tartrate, and $N$-4-methoxyphenyl]-2'-methyl-4' -(5-methyl-1,2,4-oxadiazol3-yl)-4-carboxamide hydrochloride (SB 216641) were purchased from Tocris Cookson (Bristol, UK). CNQX, bicuculline, and forskolin were dissolved in dimethyl sulfoxide at $10 \mathrm{mM}$ as a stock solution. Drugs were added to external solutions at the final concentrations shown in the text and the vehicle concentrations never exceeded $0.01 \%$. Drugs were applied using a rapid application system termed the 'Y-tube method,' described elsewhere (Akaike and Harata, 1994).

\section{RESULTS}

\section{GABAergic mIPSCs in Isolated MPOA Neurons}

Mechanically isolated MPOA neurons were bipolar or pyramidal in shape and retained short portions of their proximal dendrites. When the neurons were voltageclamped at $V_{\mathrm{H}}-60 \mathrm{mV}$ in the presence of $300 \mathrm{nM}$ TTX, $3 \mu \mathrm{M}$ CNQX, and $10 \mu \mathrm{M} \mathrm{AP5}$, spontaneous mIPSCs were observed in dissociated MPOA neurons. After rupture of the patch membrane, it took $10-20 \mathrm{~min}$ for synaptic currents to stabilize. Upon stabilization, recording of 
mIPSCs commenced. In most neurons, mIPSCs were stable for approximately $60 \mathrm{~min}$. These results indicate that presynaptic nerve terminals attached to the dissociated neurons were functional and their spontaneous activity stable within $60 \mathrm{~min}$. Superfusion of $50 \mu \mathrm{M}$ bicuculline completely and reversibly blocked spontaneous mIPSCs (Figure 1a). Figure 1b shows typical spontaneous GABAergic mIPSCs at various $V_{\mathrm{H}}$ values. The reversal potential $(-5 \mathrm{mV})$ of these mIPSCs, estimated from the current-voltage $(\mathrm{I}-\mathrm{V})$ relationship, was very similar to the theoretical $\mathrm{Cl}^{-}$Nernst equilibrium potential $\left(E_{\mathrm{Cl}}\right)$ of $-4 \mathrm{mV}$ calculated using the extracellular and intracellular $\mathrm{Cl}^{-}$ concentrations of 161 and $140 \mathrm{mM}$, respectively. These results indicate that the spontaneous mIPSCs were mediated by $\mathrm{GABA}_{\mathrm{A}}$ receptors. Figure $1 \mathrm{c}$ shows that the typical amplitude distribution of mIPSCs was roughly unimodal and somewhat skewed. The amplitudes of almost all mIPSC events in the present study were larger than $10-20 \mathrm{pA}$.

\section{5-HT ${ }_{1 \mathrm{~A}}$ Receptors Mediate Serotonergic Presynaptic Inhibition of GABAergic mIPSCs}

Superfusion of 5-HT (100 nM) decreased the frequency of GABAergic synaptic events in almost MPOA neurons. The effect of 5-HT was reversible (Figure $2 \mathrm{~b}$ ). Figure $2 \mathrm{~b}$ shows cumulative probability plots for inter-event intervals and current amplitudes of mIPSCs. Serotonin shifted the distribution curve of mIPSC frequency to the right, indicating a reduction of mIPSC frequency. The amplitude distribution was not affected. Serotonin decreased the mean mIPSC frequency to $62.4 \pm 3.2 \%$ of the mean control frequency $(P<0.01, n=23$; Control, $2.20 \pm 0.57 \mathrm{~Hz} ; 5-\mathrm{HT}$, $1.58 \pm 0.47 \mathrm{~Hz}$ ), but the mean amplitude was not affected $(98.5 \pm 4.4 \%$ of the control amplitude, $P=0.739, n=23$; Control, $61.66 \pm 3.74 \mathrm{pA}$; 5 -HT, $60.38 \pm 4.42 \mathrm{pA}$; Figure $2 \mathrm{c}$ ). These results indicate that serotonin acts presynaptically to inhibit the release probability of GABA at the synapse.

To determine which 5-HT receptor subtypes mediated the decrease in mIPSC frequency, the effects of selective $5-\mathrm{HT}_{1 \mathrm{~A}}$ and $5-\mathrm{HT}_{2}$ receptor agonists and antagonists were examined. The selective $5-\mathrm{HT}_{1 \mathrm{~A}}$ receptor agonist $8-\mathrm{OH}-\mathrm{DPAT}$ $(100 \mathrm{nM})$ reversibly decreased the mIPSC frequency in a manner similar to 5-HT itself. For example, 8-OH-DPAT reduced the mean mIPSC frequency to $61.9 \pm 9.0 \%$ of the control frequency $(P<0.01, n=6$; Control, $0.88 \pm 0.33 \mathrm{~Hz}$; 8-OH-DPAT, $0.56 \pm 0.23 \mathrm{~Hz})$ without affecting the mean amplitude $(97.6 \pm 13.3 \%$ of the control amplitude, $P=0.769, \quad n=6 ;$ Control, $43.16 \pm 4.32 \mathrm{pA} ; 8$-OH-DPAT, $43.03 \pm 7.31 \mathrm{pA}$; Figure $2 \mathrm{c}$ ). In contrast, $\alpha$-methyl-5-HT $(100 \mathrm{nM})$, a selective $5-\mathrm{HT}_{2}$ receptor agonist, did not affect mean mIPSC frequency $(97.7 \pm 13.4 \%$ of the control frequency, $\quad P=0.836, \quad n=5 ; \quad$ Control, $\quad 0.44 \pm 0.12 \mathrm{~Hz}$; a
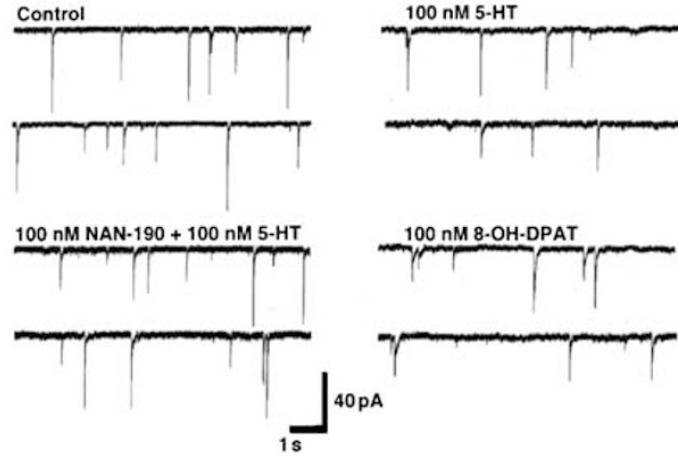

b

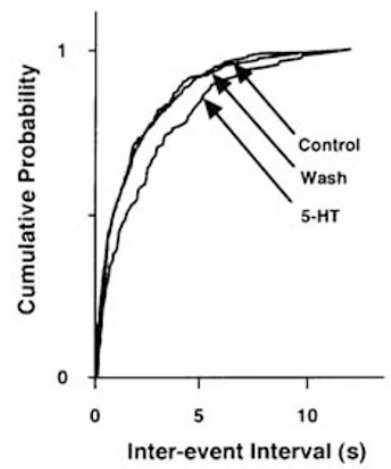

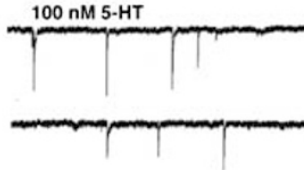

$100 \mathrm{nM} 8 \cdot \mathrm{OH} \cdot \mathrm{DPAT}$

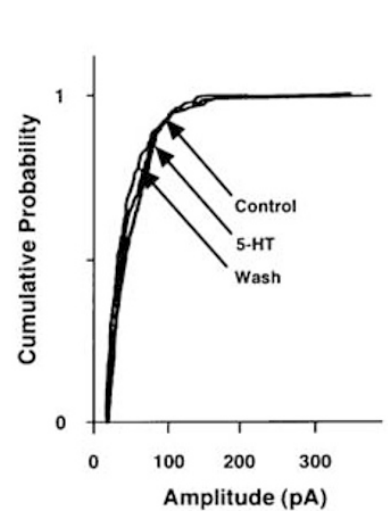

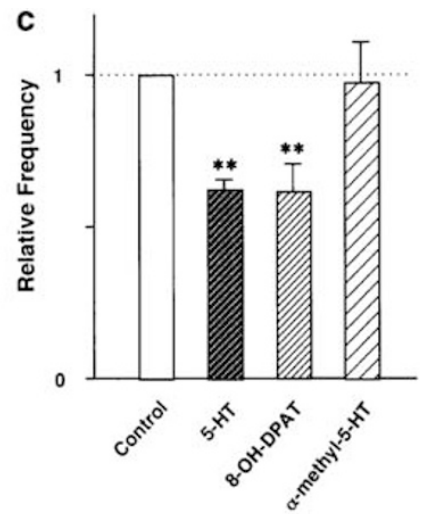
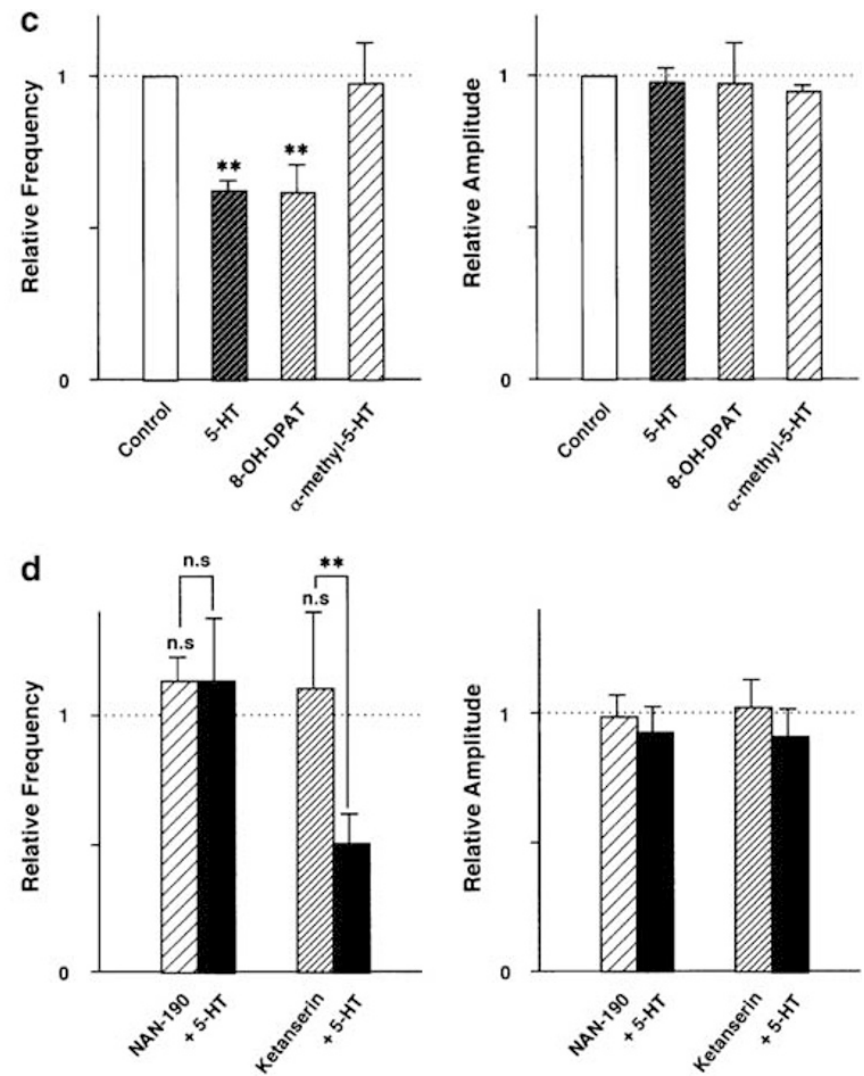

Figure 2 5-HTIA receptor-mediated presynaptic inhibition of GABAergic mIPSCs. (a) Representative recording traces of mIPSCs observed before and during the application of $100 \mathrm{nM} 5-\mathrm{HT}$ in the absence or presence of $100 \mathrm{nM}$ NAN-190, and during the application of I00 nM 8-OH-DPAT. (b) Cumulative distributions for inter-event intervals and amplitudes of mIPSCs recorded from the same neuron. (c) All frequencies and amplitudes are normalized to those of control mIPSCs. 5-HT ( $n=23), 8-\mathrm{OH}$-DPAT $(n=6), 100 \mathrm{nM} \alpha$-methyl-5-HT $(n=5)$. (d) All frequencies and amplitudes are normalized to those of control mIPSCs. NAN-190+5-HT $(n=4)$ and $100 \mathrm{nM}$ ketanserin $+5-\mathrm{HT}(n=4)$. Dashed lines in each histogram indicate the relative control. In this and subsequent figures, asterisks represent a statistically significant difference (*** $P<0.0$ I, paired two-tailed t-test). n.s. indicates $P>0.05$. 
$\alpha$-methyl-5-HT, $0.44 \pm 0.14 \mathrm{~Hz})$ or amplitude $(94.8 \pm 2.1 \%$ of the control amplitude, $P=0.524, n=5$; Control, $51.35 \pm 6.27 \mathrm{pA} ; \alpha$-methyl-5-HT, $48.81 \pm 6.39 \mathrm{pA}$; Figure $2 \mathrm{c}$ ).

The neurons were superfused with external solution containing each 5-HT antagonist for $5 \mathrm{~min}$ before simultaneous superfusion of $100 \mathrm{nM} 5-\mathrm{HT}$ with one of the antagonists. The selective $5-\mathrm{HT}_{1 \mathrm{~A}}$ receptor antagonist NAN-190 (100 nM) blocked the inhibitory effect of 5-HT on mIPSC frequency $(100.6 \pm 19.9 \%$ of the NAN-190 condition, $P=0.210, \quad n=4 ; \quad \mathrm{NAN}-190, \quad 0.41 \pm 0.10 \mathrm{~Hz}$; NAN-190 $+5-\mathrm{HT}, 0.49 \pm 0.12 \mathrm{~Hz}$ ) without affecting mIPSC amplitude $(95.8 \pm 4.3 \%$ of the NAN-190 condition, $P=0.261, n=4 ;$ NAN-190, $55.39 \pm 9.51 \mathrm{pA} ; \mathrm{NAN}-190+5-$ HT, $52.38 \pm 7.87 \mathrm{pA}$; Figure $2 \mathrm{~d})$. NAN-190 itself did not affect mIPSC frequency $(113.3 \pm 9.3 \%$ of the control frequency, $P=0.416, n=4$; Control, $0.49 \pm 0.15 \mathrm{~Hz}$; NAN$190,0.41 \pm 0.10 \mathrm{~Hz})$ or amplitude $(99.1 \pm 8.0 \%$ of the control amplitude, $P=0.651, n=4$; Control, $60.38 \pm 13.95$ pA; NAN$190,55.39 \pm 9.51 \mathrm{pA}$; Figure $2 \mathrm{~d})$. Ketanserin $(100 \mathrm{nM})$, a selective $5-\mathrm{HT}_{2}$ receptor antagonist, did not alter the inhibitory effect of 5 -HT on mIPSC frequency $(39.2 \pm 8.5 \%$ of the ketanserin condition, $P<0.01, n=4$; Ketanserin, $0.66 \pm 0.10 \mathrm{~Hz}$; Ketanserin $+5-\mathrm{HT}, 0.26 \pm 0.06 \mathrm{~Hz}$ ) or amplitude $(94.7 \pm 2.3 \%$ of the ketanserin condition, $P=0.081$, $n=4$; Ketanserin, $44.78 \pm 4.81 \mathrm{pA}$; Ketanserin $+5-\mathrm{HT}$, $42.40 \pm 4.51 \mathrm{pA}$; Figure $2 \mathrm{~d}$ ). Ketanserin itself also did not affect the frequency $(110.8 \pm 28.9 \%$ of the control frequency, $P=0.777, \quad n=4 ; \quad$ Control, $0.58 \pm 0.15 \mathrm{~Hz} ; \quad$ Ketanserin, $0.66 \pm 0.10 \mathrm{~Hz})$ or amplitude $(102.4 \pm 10.4 \%$ of the control amplitude, $P=0.837, n=4$; Control, $48.56 \pm 7.63$ pA; Ketanserin, $44.78 \pm 4.81 \mathrm{pA}$; Figure $2 \mathrm{~d}$ ) of mIPSCs. These results suggest that serotonergic modulation of GABAergic synaptic transmission in the MPOA is mediated by presynaptic $5-\mathrm{HT}_{1 \mathrm{~A}}$ receptors.

\section{Blockade of Presynaptic $\mathrm{K}^{+}$Channels does not Affect Serotonergic Inhibition of GABAergic mIPSCs}

It was previously suggested that $5-\mathrm{HT}_{1 \mathrm{~A}}$ receptor activation inhibits neuronal excitability through activation of Gprotein-coupled inwardly rectifying $\mathrm{K}^{+}$(GIRK) channels (Penington et al, 1993; Katayama et al, 1997; Jeong et al, 2001). To determine whether presynaptic activation of GIRK channels is responsible for the inhibitory effect of 5-HT on GABAergic mIPSC frequency, we tested the effects of $\mathrm{Ba}^{2+}$, which is known to block GIRK channels. $\mathrm{Ba}^{2+}(1 \mathrm{mM})$ significantly and reversibly increased mIPSC frequency to $345.7 \pm 48.8 \%$ of the control frequency $\left(P<0.05, n=4\right.$; Control, $0.49 \pm 0.09 \mathrm{~Hz} ; \mathrm{Ba}^{2+}$, $1.65 \pm 0.37 \mathrm{~Hz})$ without affecting the mean amplitude $(100.5 \pm 7.7 \%$ of the control amplitude, $P=0.961, n=4$; Control, 70.46 $\pm 3.25 \mathrm{pA} ; \mathrm{Ba}^{2+}, 71.51 \pm 9.14 \mathrm{pA}$; Figure $\left.3 \mathrm{~b}\right)$. This increase in mIPSC frequency is consistent with the expected depolarization of presynaptic nerve terminals, which should activate voltage-dependent $\mathrm{Ca}^{2+}$ channels (VDCCs). However, in the presence of $\mathrm{Ba}^{2+}, 5-\mathrm{HT}$ still reversibly decreased mIPSC frequency to $62.5 \pm 8.0 \%$ of the frequency in the $\mathrm{Ba}^{2+}$ condition $\left(P<0.05, n=4 ; \mathrm{Ba}^{2+}\right.$, $\left.1.65 \pm 0.37 \mathrm{~Hz} ; \mathrm{Ba}^{2+}+5-\mathrm{HT}, 1.01 \pm 0.27 \mathrm{~Hz}\right)$, not affecting the mean mIPSC amplitude $\left(90.7 \pm 4.3 \%\right.$ of the $\mathrm{Ba}^{2+}$ condition, $P=0.148, n=4 ; \mathrm{Ba}^{2+}, 71.51 \pm 9.14 \mathrm{pA}^{2} \mathrm{Ba}^{2+}+$ 5-HT, 64.22 \pm 7.47 pA; Figure 3b).
We also examined the effect of $4-\mathrm{AP}$, a $\mathrm{K}^{+}$channel blocker, on 5-HT-induced inhibition of mIPSCs. Superfusion of $100 \mu \mathrm{M}$ 4-AP reversibly increased mIPSC frequency to $470.7 \pm 70.4 \%$ of the control frequency $(P<0.01, \quad n=5 ; \quad$ Control, $0.69 \pm 0.14 \mathrm{~Hz} ; 4-\mathrm{AP}, \quad 3.12 \pm$ $0.59 \mathrm{~Hz})$ without altering mIPSC amplitude $(137.7 \pm 21.7 \%$ of the control amplitude, $P=0.157, n=5$; Control, $50.59 \pm 3.13 \mathrm{pA} ; 4-\mathrm{AP}, 67.23 \pm 5.58 \mathrm{pA}$; Figure $3 \mathrm{~d})$. In the presence of 4-AP, 5-HT reversibly decreased mIPSC frequency to $70.4 \pm 8.7 \%$ of the 4 -AP condition $(P<0.05$, $n=5 ; \quad 4-\mathrm{AP}, \quad 3.12 \pm 0.59 \mathrm{~Hz} ; 4-\mathrm{AP}+5-\mathrm{HT}, 2.17 \pm 0.42 \mathrm{~Hz})$ without affecting mIPSC amplitude $(98.0 \pm 3.6 \%$ of the 4 AP condition, $P=0.598, n=5$; 4 -AP, $67.23 \pm 5.58 \mathrm{pA}$; 4 -AP $+5-\mathrm{HT}, 66.32 \pm 7.23 \mathrm{pA}$; Figure $3 \mathrm{~d}$ ). Together, these results indicate that activation of presynaptic $\mathrm{K}^{+}$channels is unlikely to contribute to $5-\mathrm{HT}_{1 \mathrm{~A}}$ receptor-mediated inhibition of GABAergic mIPSCs.

\section{Presynaptic $\mathrm{Ca}^{2+}$ Channels do not Mediate Serotonergic Inhibition of GABAergic mIPSCs}

As $\mathrm{Ca}^{2+}$ influx through VDCCs plays an important part in neurotransmitter release from presynaptic nerve terminals (Wu and Saggau, 1994), we tested whether the serotonergic inhibition of GABAergic mIPSCs was mediated by modulation of VDCCs, investigating the effect of $\mathrm{Cd}^{2+}$, a general

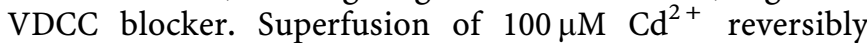
decreased not only mIPSC frequency $(37.3 \pm 6.3 \%$ of the control frequency, $P<0.01, n=6$; Control, $0.78 \pm 0.19 \mathrm{~Hz}$; $\left.\mathrm{Cd}^{2+}, \quad 0.33 \pm 0.14 \mathrm{~Hz}\right)$ but also mIPSC amplitude $(75.5 \pm 8.7 \%$ of the control amplitude, $P<0.05, n=6$; Control, $57.24 \pm 4.80 \mathrm{pA} ; \mathrm{Cd}^{2+}, 43.34 \pm 6.14 \mathrm{pA}$; Figure $3 \mathrm{f}$ ). In the presence of $\mathrm{Cd}^{2+}, 5$-HT reversibly decreased mIPSC frequency $\left(77.8 \pm 2.9 \%\right.$ of the $\mathrm{Cd}^{2+}$ condition, $P<0.05$, $\left.n=6 ; \mathrm{Cd}^{2+}, 0.33 \pm 0.14 \mathrm{~Hz} ; \mathrm{Cd}^{2+}+5-\mathrm{HT}, 0.25 \pm 0.10 \mathrm{~Hz}\right)$ but not amplitude $\left(83.3 \pm 10.2 \%\right.$ of the $\mathrm{Cd}^{2+}$ condition, $P=0.135, \quad n=6 ; \quad \mathrm{Cd}^{2+}, 43.34 \pm 6.14 \mathrm{pA} ; \quad \mathrm{Cd}^{2+}+5-\mathrm{HT}$, $33.48 \pm 1.56 \mathrm{pA}$; Figure $3 \mathrm{f})$. These results indicate that presynaptic VDCCs do not contribute to the inhibitory effect of 5-HT on mIPSC frequency.

\section{Serotonergic Inhibition of GABAergic mIPSCs Involves Activation of the Adenylyl Cyclase-cAMP and PKA Pathways}

In some regions, $5-\mathrm{HT}_{1 \mathrm{~A}}$ receptor activation is negatively coupled to cAMP formation through inhibition of adenylyl cyclase (AC) (Koyama et al, 1999). Thus, we tested the effect of forskolin, an $\mathrm{AC}$ activator, on $5-\mathrm{HT}_{1 \mathrm{~A}}$ receptor-mediated inhibition of GABAergic mIPSCs. Forskolin $(10 \mu \mathrm{M})$ significantly and reversibly increased mIPSC frequency to $150.9 \pm 18.8 \%$ of the control frequency $(P<0.05, n=7$; Control, $0.46 \pm 0.15 \mathrm{~Hz}$; Forskolin, $0.63 \pm 0.16 \mathrm{~Hz}$ ), without affecting the mean mIPSC amplitude $(99.6 \pm 5.5 \%$ of the control amplitude, $P=0.944, n=7$; Control, $66.38 \pm$ $5.88 \mathrm{pA}$; Forskolin, $64.95 \pm 4.28 \mathrm{pA}$; Figure $4 \mathrm{c}$ ). In addition, forskolin completely and reversibly blocked 5-HT-induced inhibition of GABAergic mIPSC frequency $(128.4 \pm 23.7 \%$ of the forskolin condition, $P=0.277, n=7$; Forskolin, $0.63 \pm 0.16 \mathrm{~Hz} ; \quad$ Forskolin $+5-\mathrm{HT}, \quad 0.84 \pm 0.30 \mathrm{~Hz}$ ) without altering the current amplitude $(102.4 \pm 5.7 \%$ of the forskolin condition, $P=0.689, \quad n=7$; Forskolin, $64.95 \pm 4.28 \mathrm{pA}$; 
a

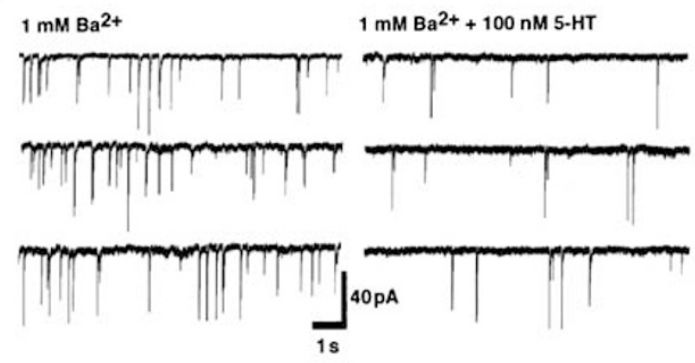

c

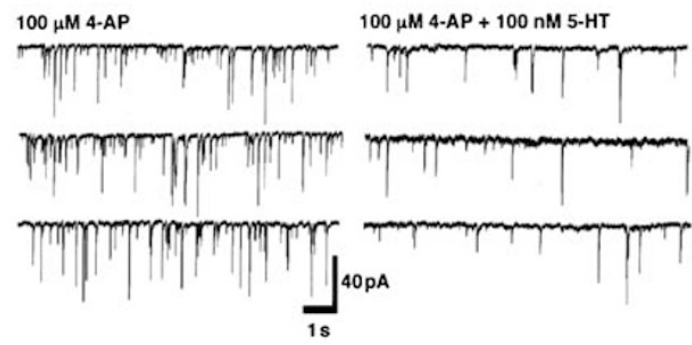

e

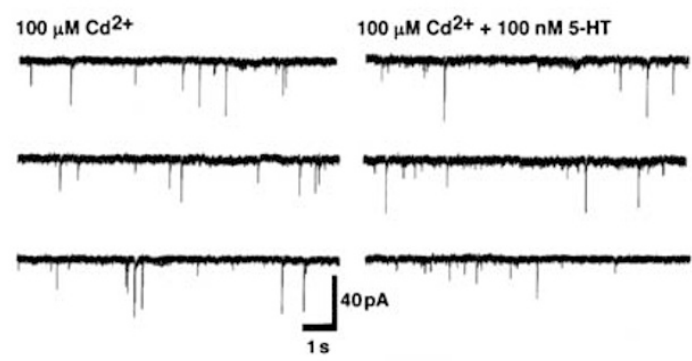

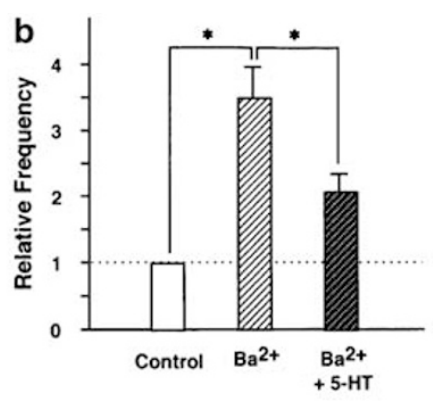
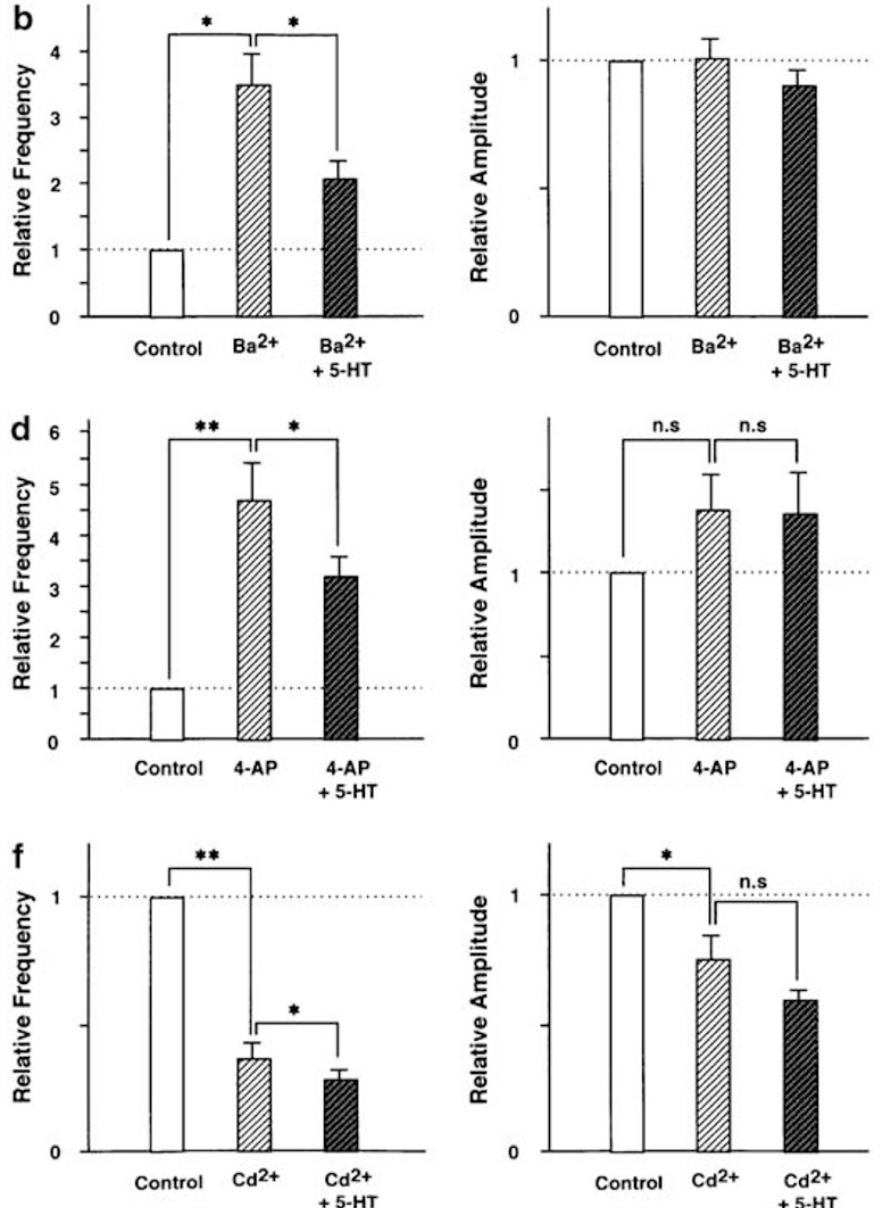

Figure $35-H T_{I A}$ receptor-mediated presynaptic inhibition of GABAergic mIPSCs is not related to the presynaptic $\mathrm{K}^{+}$channels and the presynaptic VDCCs. (a) Representative recording traces of mIPSCs show the change in the 5-HT effect in the presence of I mM Ba ${ }^{2+}$. (b) All amplitudes and frequencies are normalized to the control mIPSCs. Each column is the mean of four neurons. (c) Representative recording traces of mIPSCs show the change in the 5-HT effect in the presence of $100 \mu \mathrm{M}$ 4-AP. (d) All amplitudes and frequencies are normalized to the control mIPSCs. Each column is the mean of five neurons. (e) Representative recording traces of mIPSCs show the change in the 5-HT effect with external solution containing I00 $\mu \mathrm{M}$ C $\mathrm{d}^{2+}$. (f) All amplitudes and frequencies are normalized to the control mIPSCs. Each column is the mean of six neurons. Dashed lines in each histogram indicate the relative control. Asterisks represent a statistically significant difference ( $P<0.05$; $* * P<0.0$ I, paired two-tailed t-test). n.s. indicates $P>0.05$.

Forskolin + 5-HT, $66.29 \pm 5.15 \mathrm{pA}$; Figure 4c). These results indicate that reduction of cAMP formation by $5-\mathrm{HT}_{1 \mathrm{~A}}$ receptor activation is closely related to serotonergic inhibition of GABAergic mIPSCs.

It is well known that in the CNS a change in intracellular cAMP concentration affects a variety of cellular signaling via cAMP-dependent protein kinase A (PKA) (Bouron, 2001). To address the possible involvement of PKA in the serotonergic modulation of GABA release, we examined the effects of $\mathrm{H}-89$, a selective PKA inhibitor, on $5-\mathrm{HT}_{1 \mathrm{~A}}$ receptor-mediated inhibition of GABAergic mIPSCs. H-89 $(100 \mathrm{nM})$ significantly and reversibly decreased basal GABAergic mIPSC frequency to $61.7 \pm 5.3 \%$ of the control frequency $(P<0.01, n=10$; Control, $0.45 \pm 0.11 \mathrm{~Hz} ; \mathrm{H}-89$, $0.29 \pm 0.09 \mathrm{~Hz}$ ) without affecting the mean MIPSC amplitude $(123.9 \pm 13.4 \%$ of the control amplitude, $P=0.108, n=10$; Control, $53.99 \pm 3.88 \mathrm{pA}$; H-89, $64.52 \pm 6.60 \mathrm{pA}$; Figure $4 \mathrm{f}$ ). However, H-89 completely blocked 5-HT-induced inhibition of GABA release; in the presence of both 5-HT and H89 the mean mIPSC frequency was $95.4 \pm 8.8 \%$ of the H- 89 control frequency $(P=0.612, n=10 ; \mathrm{H}-89,0.29 \pm 0.09 \mathrm{~Hz}$;
$\mathrm{H}-89+5-\mathrm{HT}, \quad 0.28 \pm 0.09 \mathrm{~Hz}$; Figure $4 \mathrm{f}$ ). This finding indicates that $5-\mathrm{HT}_{1 \mathrm{~A}}$ receptor-mediated inhibition of GABAergic mIPSCs is likely to be dependent on a decrease in PKA activity.

\section{Glutamatergic mEPSCs in Isolated MPOA Neurons}

When dissociated MPOA neurons were voltage-clamped at $V_{\mathrm{H}}-60 \mathrm{mV}$ in the presence of $300 \mathrm{nM}$ TTX and $10 \mu \mathrm{M}$ bicuculline, spontaneous mEPSCs were observed. These spontaneous mEPSCs were completely and reversibly blocked by the superfusion of $10 \mu \mathrm{M}$ CNQX, an antagonist of the AMPA-type glutamate receptor (Figure 5a). In the $\mathrm{I}-\mathrm{V}$ relationship, the reversal potential of the spontaneous mEPSCs was close to $0 \mathrm{mV}$ (Figure 5b). These results indicate that the spontaneous mEPSCs were generated by currents passing through AMPA receptor-activated cation channels. Figure $5 \mathrm{c}$ shows that the mEPSC amplitude distribution was deviated from a Gaussian and skewed to the right. The amplitudes of almost all mEPSC events in the present study were larger than 5-10 pA. 
a
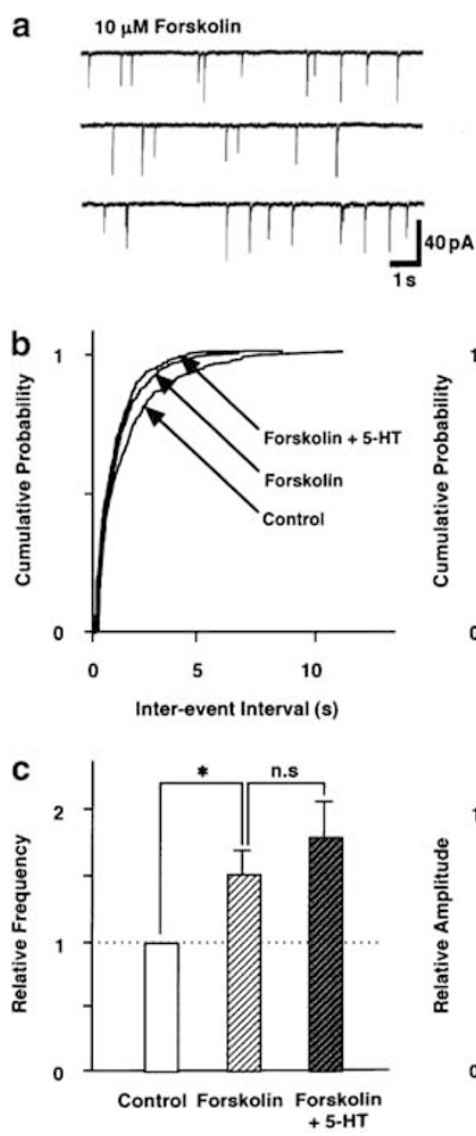

$10 \mu \mathrm{M}$ Forskolin $+100 \mathrm{nM} 5-\mathrm{HT}$
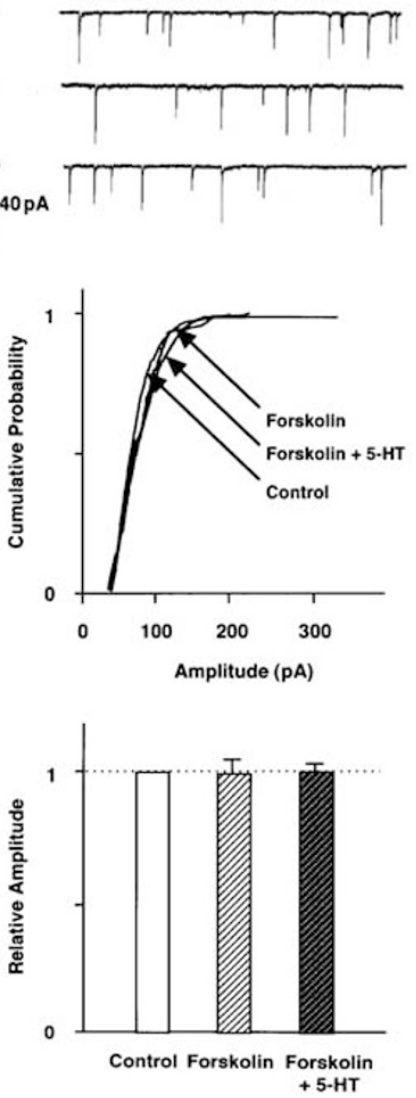

d
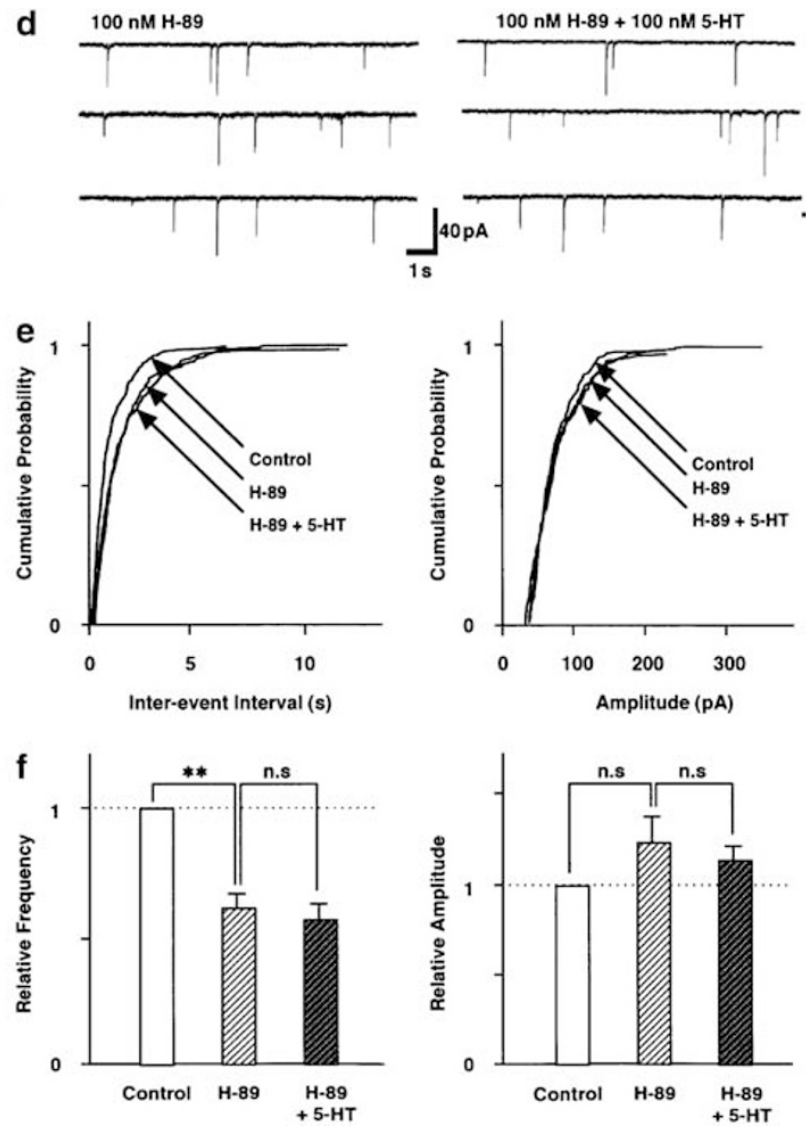

Figure $45-\mathrm{HT}_{\text {IA }}$ receptor-mediated presynaptic inhibition of GABAergic mIPSCs is coupled to the AC-cAMP signal-transduction pathway. (a) Representative recording traces of mIPSCs show the change in the 5-HT effect in the presence of IO $\mu \mathrm{M}$ forskolin. (b) Cumulative distributions for mIPSC inter-event intervals and amplitudes recorded from the same neuron. (c) Each column is the mean of seven neurons. All frequencies and amplitudes are normalized to those of control mIPSCs. (d) Representative recording traces of mIPSCs show the change in the 5-HT effect in the presence of I00 $\mathrm{nM} \mathrm{H-89.}$ (e) Cumulative distributions for mIPSC inter-event intervals and amplitudes recorded from the same neuron. (f) Each column is the mean of I0 neurons. All frequencies and amplitudes are normalized to those of control mIPSCs. Dashed lines in each histogram indicate the relative control. Asterisks represent a statistically significant difference ( $* P<0.05$; $* * P<0.0$ I, paired two-tailed $t$-test). n.s. indicates $P>0.05$.

\section{5-HT ${ }_{1 \mathrm{~B}}$ Receptors Mediate Serotonergic Presynaptic Inhibition of Glutamatergic mEPSCs}

Superfusion of 5-HT (100 nM) reversibly decreased the frequency of glutamatergic synaptic events in MPOA neurons (Figure 6b). Figure $6 \mathrm{~b}$ shows cumulative probability plots for mEPSC inter-event intervals and current amplitudes. Serotonin shifted the distribution curve of mEPSC frequency to the right, indicating a reduction in frequency. The amplitude distribution was not affected. Serotonin reversibly decreased the mean mEPSC frequency to $64.4 \pm 8.4 \%$ of the control frequency $(P<0.01, n=11$; Control, $0.18 \pm 0.06 \mathrm{~Hz}$; $5-\mathrm{HT}, 0.12 \pm 0.03 \mathrm{~Hz}$ ) but did not affect the mean amplitude $(97.1 \pm 5.2 \%$ of the control, $P=0.595, n=11$; Control, $21.29 \pm 1.93 \mathrm{pA} ; 5-\mathrm{HT}, 20.33 \pm$ $1.61 \mathrm{pA}$; Figure $6 \mathrm{c})$. These results indicate that serotonin acts presynaptically to inhibit the release probability of glutamate at the synapse.

To identify the subtypes of 5-HT receptors mediating the decrease in mEPSC frequency, we examined the effects of selective $5-\mathrm{HT}_{1 \mathrm{~A}}, 5-\mathrm{HT}_{1 \mathrm{~B}}$, and $5-\mathrm{HT}_{2}$ receptor agonists and antagonists. The selective $5-\mathrm{HT}_{1 \mathrm{~B}}$ receptor agonist CGS $12066 \mathrm{~B}(100 \mathrm{nM})$ reversibly decreased the mEPSC frequency in a manner similar to 5-HT itself. CGS 12066B reduced the mean EPSC frequency to $75.3 \pm 9.1 \%$ of the control frequency $(P<0.05, n=8$; Control, $0.38 \pm 0.08 \mathrm{~Hz}$; CGS $12066 \mathrm{~B}, 0.28 \pm 0.07 \mathrm{~Hz})$ without affecting the mean amplitude $(107.3 \pm 4.8 \%$ of the control amplitude, $P=0.169$, $n=8$; Control, $25.16 \pm 2.22 \mathrm{pA}$; CGS $12066 \mathrm{~B}, 26.66 \pm 2.39 \mathrm{pA}$; Figure $6 \mathrm{c})$. In contrast, 8 -OH-DPAT $(100 \mathrm{nM})$, a selective $5-\mathrm{HT}_{1 \mathrm{~A}}$ receptor agonist, and $\alpha$-methyl-5-HT $(100 \mathrm{nM})$, a selective $5-\mathrm{HT}_{2}$ receptor agonist, did not affect mEPSC frequency (8-OH-DPAT: $82.7 \pm 9.6 \%$ of the control frequency, $P=0.104, n=11$; Control, $0.23 \pm 0.07 \mathrm{~Hz}$; 8 - OHDPAT, $0.20 \pm 0.07 \mathrm{~Hz} ; \alpha$-methyl-5-HT: $95.9 \pm 7.4 \%$ of the control frequency, $P=0.602, n=7$; Control, $0.25 \pm 0.08 \mathrm{~Hz}$; $\alpha$-Methyl-5-HT, $0.23 \pm 0.07 \mathrm{~Hz}$ ) or amplitude (8-OH-DPAT: $97.2 \pm 2.5 \%$ of the control amplitude, $P=0.285, n=11$; Control, $27.12 \pm 3.42 \mathrm{pA}$; 8 -OH-DPAT, $26.42 \pm 3.37 \mathrm{pA} ; \alpha-$ methyl-5-HT: $98.5 \pm 3.4 \%$ of the control amplitude, $P=0.683, n=7$; Control, $22.24 \pm 3.74 \mathrm{pA} ; \alpha$-methyl-5-HT, $21.85 \pm 3.71 \mathrm{pA}$; Figure $6 \mathrm{c}$ ).

The neurons were superfused with external solution containing each 5-HT antagonist for 5 min before simultaneous superfusion of $100 \mathrm{nM} 5-\mathrm{HT}$ with one of the antagonists. The selective $5-\mathrm{HT}_{1 \mathrm{~B}}$ receptor antagonist $\mathrm{SB}$ $216641(100 \mathrm{nM})$ blocked the action of 5 -HT on mEPSC frequency $(110.8 \pm 12.9 \%$ of the SB 216641 condition, 

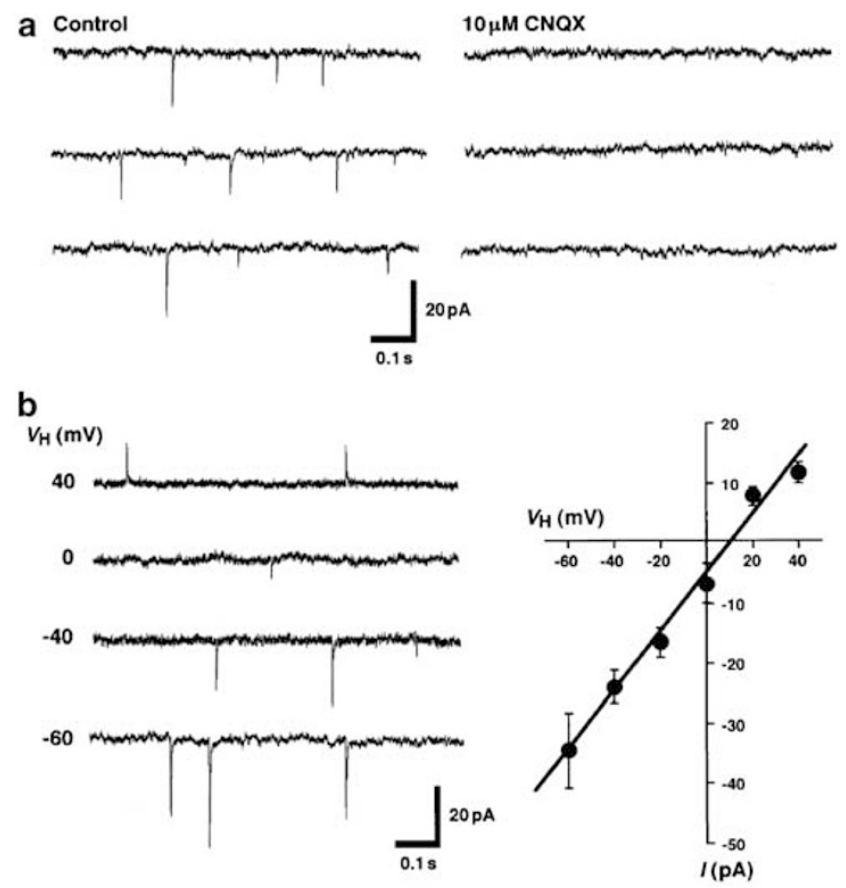

C

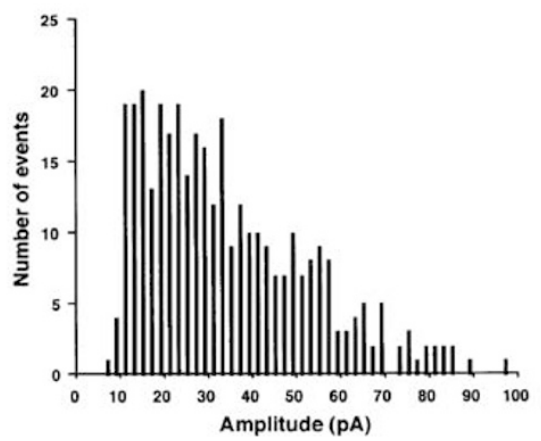

Figure 5 Glutamatergic $m E P S C s$ in mechanically isolated MPOA neurons. (a) In the presence of $300 \mathrm{nM} \Pi \mathrm{TX}$ and $10 \mu \mathrm{M}$ bicuculline, superfusion of $10 \mu \mathrm{M} C N Q X$ completely and reversibly blocked mEPSCs in isolated MPOA neurons $\left(V_{H}=-60 \mathrm{mV}\right)$. (b) Traces of $\mathrm{mEPSC}$ recorded at $V_{H}$ of $-60,-40,0$, and $+40 \mathrm{mV}$. I-V curve for the mean amplitude of mEPSCs recorded at various $V_{H} s$. Each point represents the mean of four neurons. (c) A histogram showing typical amplitude distribution of mEPSCs. The amplitudes of 353 events detected at the threshold of I pA were plotted. Amplitudes of almost all events were larger than $5 \mathrm{pA}$. The bin size was 2. $V_{H}=-60 \mathrm{mV}$

$P=0.449, n=5 ;$ SB $216641,0.20 \pm 0.07 \mathrm{~Hz} ;$ SB $216641+$ $5-\mathrm{HT}, 0.22 \pm 0.07 \mathrm{~Hz}$ ) without affecting mEPSC amplitude $(95.0 \pm 7.6 \%$ of the SB 216641 condition, $P=0.545, n=5$; SB $216641,26.85 \pm 4.07 \mathrm{pA}$; SB $216641+5-\mathrm{HT}, 24.50 \pm 2.65 \mathrm{pA}$; Figure 6d). SB 216641 itself did not affect mEPSC frequency (102.9 $\pm 7.8 \%$ of the control frequency, $P=0.730, n=5$; Control, $0.19 \pm 0.05 \mathrm{~Hz}$; SB 216641, $0.20 \pm 0.07 \mathrm{~Hz}$ ) or amplitude $(109.4 \pm 4.7 \%$ of the control amplitude, $P=0.115, \quad n=5$; Control, 24.34 $\pm .13 \mathrm{pA} ;$ SB 216641, $26.85 \pm 4.07 \mathrm{pA}$; Figure $6 \mathrm{~d})$. In contrast, NAN-190 $(100 \mathrm{nM})$, a selective $5-\mathrm{HT}_{1 \mathrm{~A}}$ receptor antagonist, did not alter the inhibitory effect of 5-HT on mEPSC frequency $(58.5 \pm 7.4 \%$ of the NAN-190 condition, $P<0.01, n=7$; NAN-190, $0.38 \pm 0.22 \mathrm{~Hz} ; \mathrm{NAN}-190+5-\mathrm{HT}, 0.20 \pm 0.09 \mathrm{~Hz}$ ) or affect mEPSC amplitude $(95.7 \pm 6.9 \%$ of the NAN-190 condition, $P=0.559, n=7$; NAN-190, 27.46 \pm 2.15 pA; NAN$190+5-\mathrm{HT}, 25.92 \pm 2.13 \mathrm{pA}$; Figure 6d). NAN-190 itself did not affect mEPSC frequency $(82.0 \pm 6.7 \%$ of the control frequency, $P=0.198, n=5$; Control, $0.43 \pm 0.21 \mathrm{~Hz}$; NAN$190,0.38 \pm 0.22 \mathrm{~Hz})$ or amplitude $(84.0 \pm 4.5 \%$ of the control amplitude, $P=0.159, n=5$; Control, $33.52 \pm 3.47 \mathrm{pA}$; NAN$190,27.46 \pm 2.15 \mathrm{pA}$; Figure $6 \mathrm{~d}$ ). These findings indicate that serotonergic modulation of glutamatergic synaptic transmission might be mediated by presynaptic $5-\mathrm{HT}_{1 \mathrm{~B}}$ receptors.

\section{PKA Mediates the Serotonergic Inhibition of Glutamatergic mEPSCs}

As the $5-\mathrm{HT}_{1 \mathrm{~B}}$ receptor is a G-protein-coupled receptor, and its activation decreases AC activity (Maroteaux et al, 1992; $\mathrm{Ng}$ et al, 1993), we tested the effect of forskolin, an AC activator, on $5-\mathrm{HT}_{1 \mathrm{~B}}$ receptor-mediated inhibition of glutamatergic mEPSCs. Forskolin $(10 \mu \mathrm{M})$ significantly and reversibly increased mEPSC frequency to $162.2 \pm$ $25.5 \%$ of the control frequency $(P<0.05, n=9$; Control, $0.11 \pm 0.02 \mathrm{~Hz}$; Forskolin, $0.17 \pm 0.04 \mathrm{~Hz}$ ) without affecting the mean mEPSC amplitude $(101.3 \pm 6.7 \%$ of the control amplitude, $P=0.848, n=9$; Control, $30.04 \pm 3.50 \mathrm{pA}$; Forskolin, $31.78 \pm 4.04 \mathrm{pA}$; Figure $7 \mathrm{c}$ ). In addition, forskolin completely blocked 5-HT-induced reduction of glutamatergic mEPSC frequency $(112.6 \pm 19.1 \%$ of the forskolin condition, $P=0.530, n=9$; Forskolin, $0.17 \pm 0.04 \mathrm{~Hz}$; Forskolin +5 -HT, $0.18 \pm 0.04 \mathrm{~Hz}$ ) without altering the current amplitude $(99.9 \pm 3.7 \%$ of the forskolin condition, $P=$ 0.979, $n=9$; Forskolin, $31.78 \pm 4.04 \mathrm{pA}$; Forskolin + 5-HT, $32.53 \pm 4.18 \mathrm{pA}$; Figure $7 \mathrm{c}$ ). These results suggest that reduction of cAMP formation by $5-\mathrm{HT}_{1 \mathrm{~B}}$ receptor activation is closely related to serotonergic inhibition of glutamatergic mEPSCs.

To investigate the possibility that PKA is involved in the serotonergic modulation of glutamate release, we tested the effects of $\mathrm{H}-89$, a selective PKA inhibitor, on $5-\mathrm{HT}_{1 \mathrm{~B}}$ receptor-mediated inhibition of glutamatergic mEPSCs. $\mathrm{H}-89$ (100 nM) significantly and reversibly decreased basal glutamatergic mEPSC frequency to $64.4 \pm 8.6 \%$ of the control frequency $(P<0.01, n=7$; Control, $0.16 \pm 0.03 \mathrm{~Hz}$; $\mathrm{H}-89,0.11 \pm 0.03 \mathrm{~Hz}$ ) without affecting the mean mEPSC amplitude $(97.4 \pm 9.2 \%$ of the control amplitude, $P=0.787$, $n=7$; Control, $24.32 \pm 3.74 \mathrm{pA} ; \quad \mathrm{H}-89,22.41 \pm 2.49 \mathrm{pA}$; Figure $7 \mathrm{f})$. However, $\mathrm{H}-89$ completely blocked serotonergic inhibition of glutamate release; in the presence of 5-HT and $\mathrm{H}-89$ the mean mEPSC frequency was $111.1 \pm 13.1 \%$ of the $\mathrm{H}-89$ control value $(P=0.432, n=7 ; \mathrm{H}-89,0.11 \pm 0.03 \mathrm{~Hz}$; $\mathrm{H}-89+5-\mathrm{HT}, \quad 0.11 \pm 0.03 \mathrm{~Hz}$; Figure $7 \mathrm{f})$. These results suggest that $5-\mathrm{HT}_{1 \mathrm{~B}}$ receptor-mediated inhibition of glutamatergic mEPSCs is dependent on a decrease in PKA activity.

\section{DISCUSSION}

The present study was designed to investigate the mechanisms underlying the inhibitory effect of 5-HT on presynaptic GABA and glutamate release in MPOA neurons. Our principal finding is that 5 -HT reversibly suppressed both inhibitory and excitatory transmission in MPOA 
a
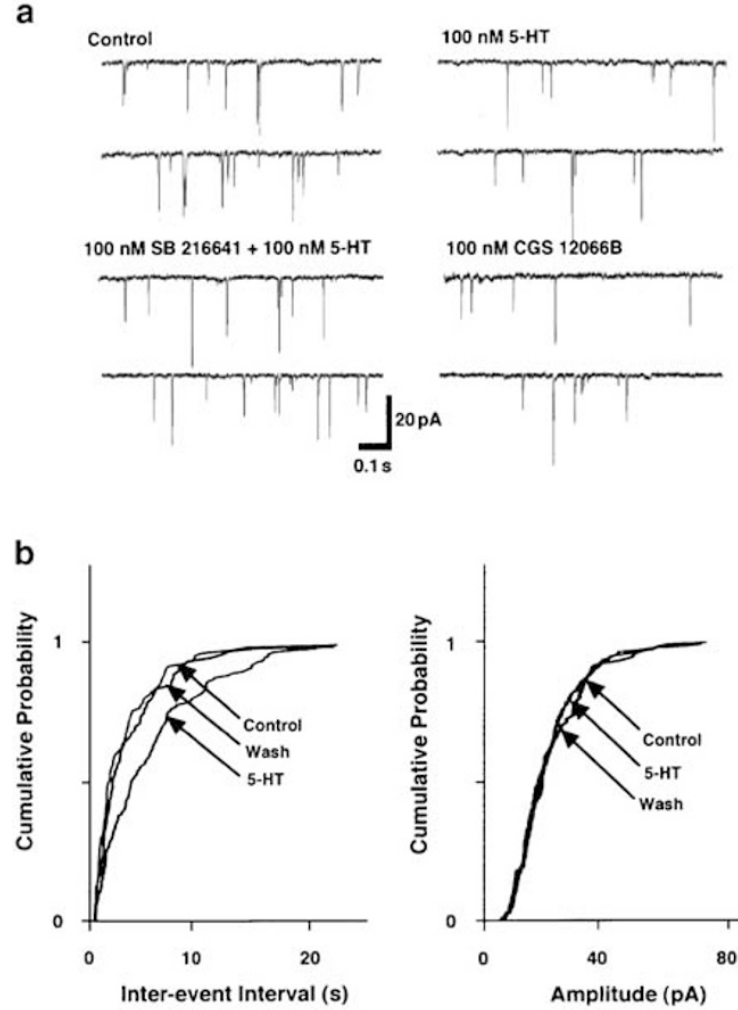
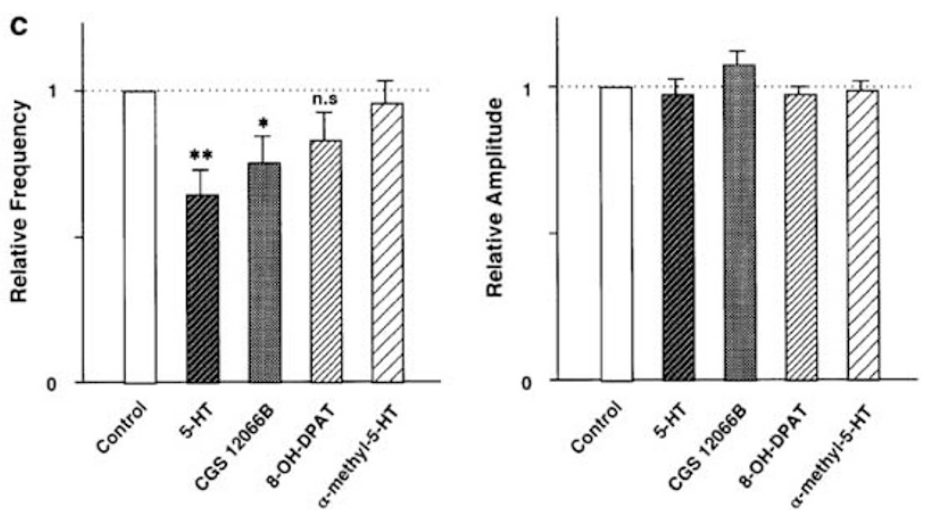

d
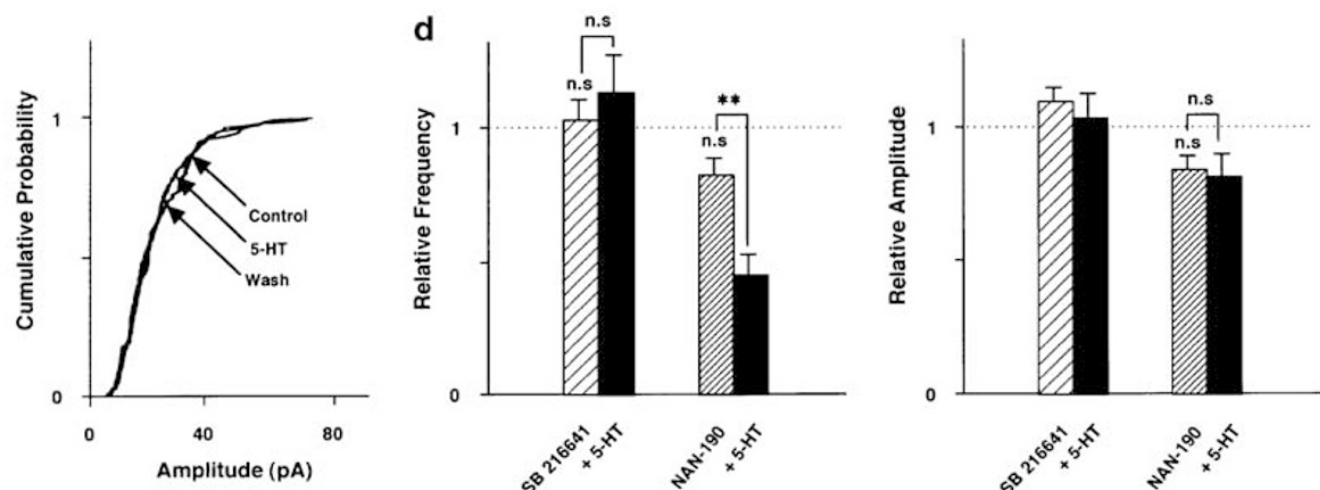

Figure 6 5-HT IB receptor-mediated presynaptic inhibition of glutamatergic mEPSCs. (a) Representative recording traces of mEPSCs observed before and during the application of $100 \mathrm{nM} 5-\mathrm{HT}$ in the absence or presence of $100 \mathrm{nM}$ SB 2 1664 I, and during the application of I00 nM CGS I 2066B. (b) Cumulative distributions for mEPSC inter-event intervals and amplitudes recorded from the same neuron. (c) All frequencies and amplitudes are normalized to those of control mEPSCs. 5-HT $(n=1 \mathrm{I})$, CGS I 2066B $(n=8), 100 \mathrm{nM} 8-\mathrm{OH}$-DPAT $(n=1 \mathrm{I})$, I00 nM $\alpha$-methyl-5-HT $(n=7)$. (d) All frequencies and amplitudes are normalized to those of control mEPSCs. SB $216641+5-H T(n=5)$ and $100 \mathrm{nM}$ NAN-190 + 5-HT $(n=7)$. Dashed lines in each histogram indicate the relative control. Asterisks represent a statistically significant difference ( $P<0.05$; ${ }^{*} * P<0.0$ l, paired two-tailed $t$-test). n.s. indicates $P>0.05$.

neurons. The inhibitory response of 5-HT was not different between male and female rats. It appears that serotonin inhibits GABAergic mIPSCs by activation of $5-\mathrm{HT}_{1 \mathrm{~A}}$ receptors and inhibition of PKA-dependent signaling, whereas it inhibits glutamatergic mEPSCs by activation of $5-\mathrm{HT}_{1 \mathrm{~B}}$ receptors in the presynaptic nerve terminals of MPOA neurons and inhibition of PKA-dependent signaling.

\section{5-HT ${ }_{1 \mathrm{~A}}$ Receptor-Mediated Inhibition of Spontaneous GABA Release}

It has been suggested that activation of presynaptic $5-\mathrm{HT}_{1 \mathrm{~A}}$ receptors mediates a decrease in GABA release in the rat locus coeruleus, rat hippocampal CA1, and guinea-pig enteric neurons (Bobker and Williams, 1989; Pan and Galligan, 1994; Schmitz et al, 1995). In the present study, 5-HT reversibly decreased GABAergic mIPSC frequency without affecting the amplitude distribution (Figure 2), indicating that 5-HT acts presynaptically to inhibit spontaneous GABA release from the presynaptic nerve terminals of MPOA neurons. This effect was completely blocked by NAN-190, a selective $5-\mathrm{HT}_{1 \mathrm{~A}}$ receptor antagonist, and mimicked by $8-\mathrm{OH}-\mathrm{DPAT}$, a $5-\mathrm{HT}_{1 \mathrm{~A}}$ receptor agonist (Figure 2). Thus, the effect of 5-HT on GABAergic presynaptic nerve terminals in the MPOA seems to be mediated primarily by $5-\mathrm{HT}_{1 \mathrm{~A}}$ receptors.
Intracellular Signal-Transduction Pathway of 5- $\mathrm{HT}_{1 \mathrm{~A}}$ Receptor-Mediated Inhibition of GABAergic Transmission

Serotonin $_{1 \mathrm{~A}}$ receptors commonly couple to G-proteins, and activation of these receptors leads to inhibition of AC. At least three possible mechanisms can be proposed for the Gprotein-coupled presynaptic inhibition of GABA release by 5-HT. First, activation of $\mathrm{K}^{+}$channels could hyperpolarize the presynaptic membrane, resulting in decreased GABA release (Umemiya and Berger, 1995; Bijak and Misgeld, 1997). Second, inhibition of $\mathrm{Ca}^{2+}$ influx into the nerve terminal via the closing of VDCCs could decrease exocytosis (Umemiya and Berger, 1995). Third, inhibition of the ACcAMP signal-transduction pathway could decrease neurotransmitter release (Dumuis et al, 1988).

Serotonin is known to directly modulate $\mathrm{K}^{+}$channels via $\mathrm{G}$-proteins (Oh et al, 1995). However, the present findings do not suggest a role of $\mathrm{K}^{+}$channels in the presynaptic serotonergic modulation of GABAergic mIPSCs (Figure 3). This is consistent with previous results showing that serotonin does not affect presynaptic $\mathrm{K}^{+}$channels in the hippocampus (Schmitz et al, 1995). VDCCs are also directly modulated by 5-HT via G-proteins (Rhee et al, 1996) and are known to trigger neurotransmitter release. But in the present study, modulation of GABAergic transmission occurred independent of $\mathrm{Ca}^{2+}$ (Figure 3), which is 
a
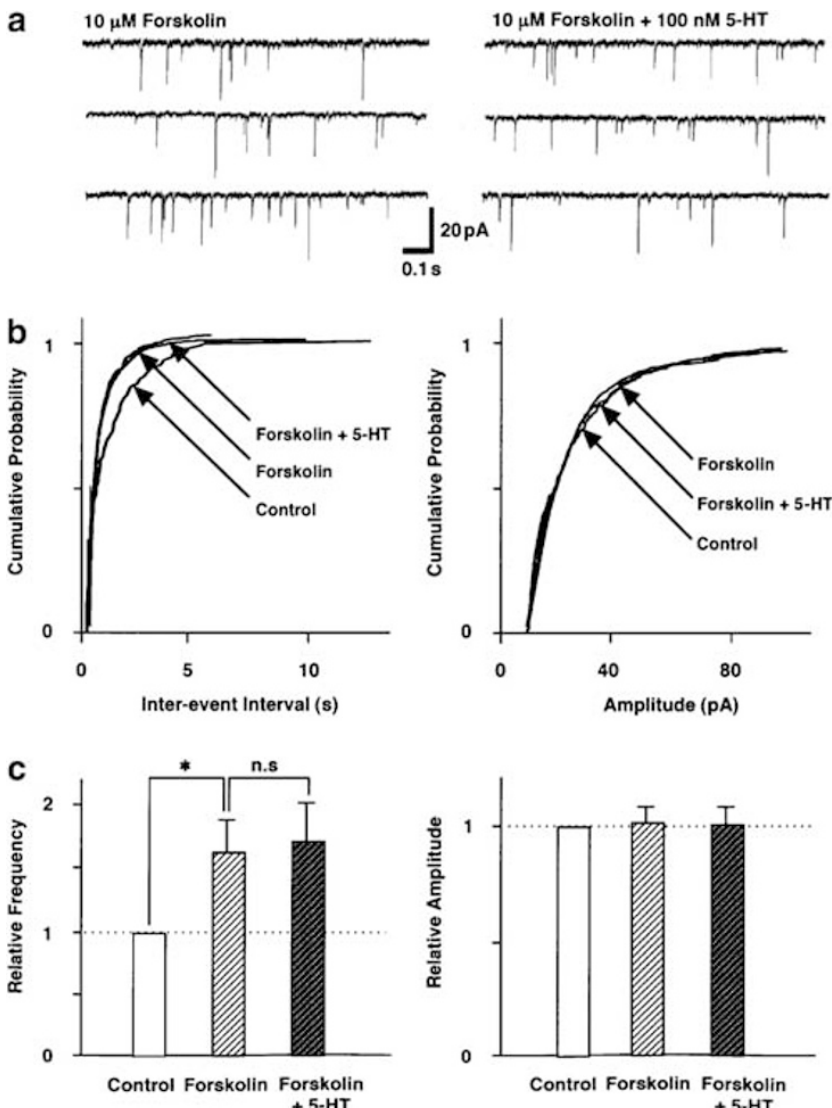
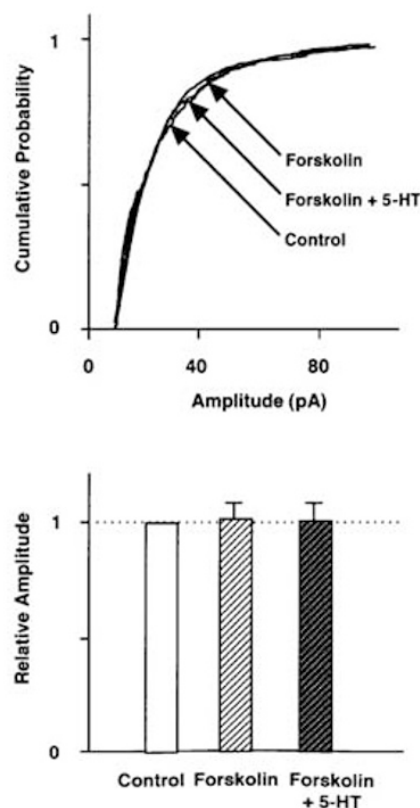

d $\quad 100 \mathrm{nM} \mathrm{H}-89$
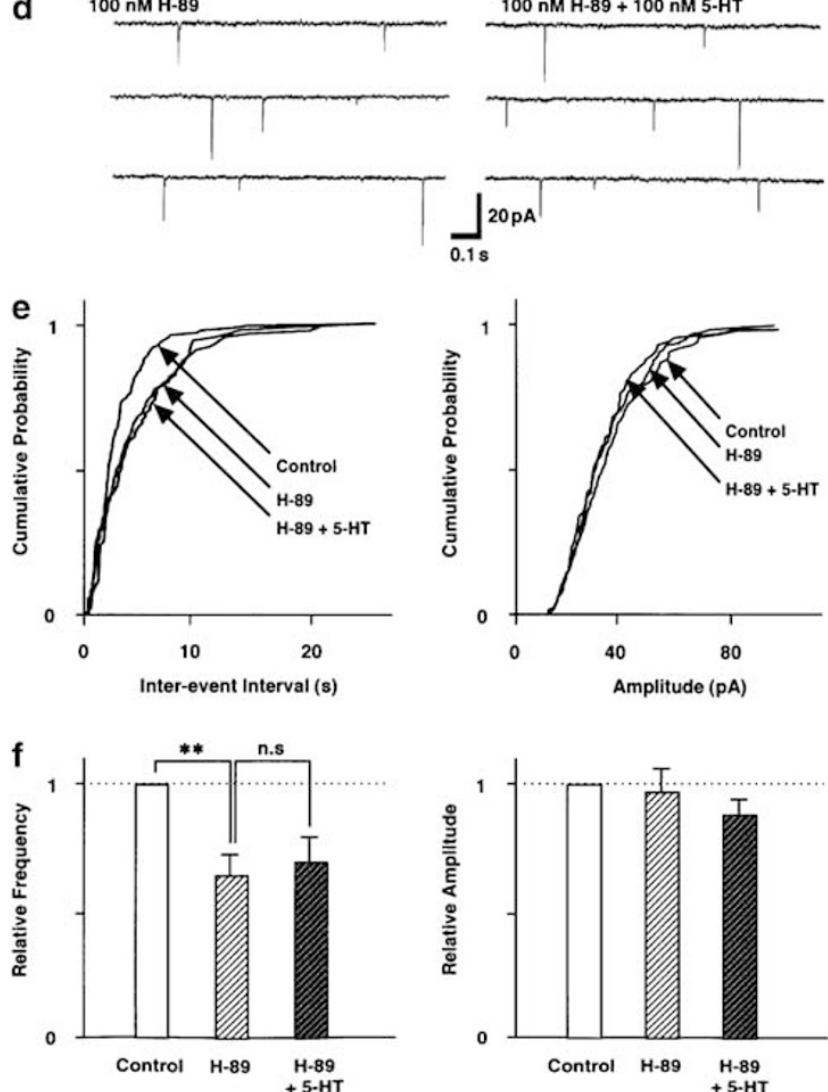

Figure $75-\mathrm{HT}_{\mathrm{IB}}$ receptor-mediated presynaptic inhibition of glutamatergic mEPSCs is coupled to the AC-cAMP signal-transduction pathway. (a) Representative recording traces of mEPSCs show the change in the 5-HT effect in the presence of $10 \mu \mathrm{M}$ forskolin. (b) Cumulative distributions for mEPSC inter-event intervals and amplitudes recorded from the same neuron. (c) Each column is the mean of nine neurons. All frequencies and amplitudes are normalized to those of control mEPSCs. (d) Representative recording traces of mEPSCs show the change in the 5-HT effect in the presence of I00 nM $\mathrm{H}$-89. (e) Cumulative distributions for mEPSC inter-event intervals and amplitudes recorded from the same neuron. (f) Each column is the mean of seven neurons. All frequencies and amplitudes are normalized to those of control mEPSCs. Dashed lines in each histogram indicate the relative control. Asterisks represent a statistically significant difference $\left(* P<0.05\right.$; ${ }^{*} P<0.0$ I, paired two-tailed $t$-test). n.s. indicates $P>0.05$.

consistent with studies of presynaptic inhibition in the hippocampus (Scanziani et al, 1992; Thompson et al, 1993).

Activation of the AC-cAMP signal-transduction pathway directly facilitates presynaptic neurotransmitter release in rat central neurons (Chavez-Noriega and Stevens, 1994; Chen and Regehr, 1997; Capogna et al, 1995; Trudeau et al, 1996). The proteins synapsin I and II, which are active in the vesicular release process, are phosphorylated by cAMPdependent kinase, and synapsin phosphorylation increases the number of synaptic vesicles in the releasable pool (Greengard et al, 1993). Reduction of cAMP might reduce PKA activity, which in turn would decrease the amount of phosphorylated synapsins. In light of this fact and the current results (Figure 4), we propose that inhibition of AC-cAMP signal transduction by 5-HT might lead to dephosphorylation of proteins on synaptic vesicles in presynaptic nerve terminals, causing a decrease in presynaptic GABA release.

\section{5-HT ${ }_{1 \mathrm{~B}}$ Receptor-Mediated Inhibition of Spontaneous Glutamate Release}

Our finding of $5-\mathrm{HT}_{1 \mathrm{~B}}$ receptor-mediated presynaptic inhibition of glutamate release in the MPOA adds to a growing literature indicating powerful presynaptic inhibitory effects of 5 - $\mathrm{HT}$ mediated by $5-\mathrm{HT}_{1 \mathrm{~B}}$ receptors on axonal processes (Boschert et al, 1994) in several regions of the CNS, including the cerebellum (Raiteri et al, 1986), spinal cord (Wu et al, 1991), midbrain (Johnson et al, 1992), cortex (Tanaka and North, 1993), tectum (Mooney et al, 1994), brainstem (Singer et al, 1996), and basal forebrain (Muramatsu et al, 1998). In the present study, 5-HT reversibly decreased glutamatergic mEPSC frequency without affecting the amplitude distribution (Figure 6), indicating that $5-\mathrm{HT}$ acts presynaptically to inhibit spontaneous glutamate release from the presynaptic nerve terminals of MPOA neurons. Moreover, this effect was completely blocked by $\mathrm{SB} 216641$, a selective $5-\mathrm{HT}_{1 \mathrm{~B}}$ receptor antagonist, and mimicked by CGS $12066 \mathrm{~B}$, a $5-\mathrm{HT}_{1 \mathrm{~B}}$ receptor agonist (Figure 6). Thus, 5-HT seems to act primarily on $5-\mathrm{HT}_{1 \mathrm{~B}}$ receptors on the glutamatergic presynaptic nerve terminals in the MPOA.

Although the majority of proximal dendrites are still attached to the neurons, the mechanical dissociation can alter the majority of distal dendrites. Although the remaining dendritic as well as somatic synapses are well elucidated to be still functioning (Akaike and Moorhouse, 2003), it can not be ruled out that the dendritic synapses 
may be modulated in a different manner shown in the present study.

\section{Intracellular Signal-Transduction Pathway of 5-HT $1 \mathrm{~B}$ Receptor-Mediated Inhibition of Glutamatergic Transmission}

The mechanism by which activation of $5-\mathrm{HT}_{1 \mathrm{~B}}$ receptors in the presynaptic terminals modulates transmitter release is unknown. 5- $\mathrm{HT}_{1 \mathrm{~B}}$ receptors are negatively coupled to AC (Maroteaux et al, 1992; Ng et al, 1993). Thus, a decrease in the production of cAMP may be presumed to regulate the availability of free $\mathrm{Ca}^{2+}$ at the site of neurotransmitter release or alter the sensitivity of the $\mathrm{Ca}^{2+}$ release machinery by a variety of possible mechanisms. The ability of cAMP to serve as a long-range second messenger provides a mechanism for modulation of neurotransmitter release via activation of $5-\mathrm{HT}_{1 \mathrm{~B}}$ receptors in the presynaptic terminal (Kasai and Petersen, 1994). Together with the current results (Figure 7), this suggest that serotonergic inhibition of AC-cAMP signal transduction might lead to dephosphorylation of proteins on synaptic vesicles in the presynaptic nerve terminals, decreasing synaptic glutamate transmission. This conclusion is partly supported by previous findings showing that $5-\mathrm{HT}_{1 \mathrm{~B}}$ activation reduces forskolin-stimulated cAMP production in cultured cell lines (Maroteaux et al, 1992; $\mathrm{Ng}$ et al, 1993). However, further studies are needed to definitively identify the signaltransduction mechanism for $5-\mathrm{HT}_{1 \mathrm{~B}}$ receptor-mediated inhibition of glutamatergic transmission.

\section{Physiological Implications}

MPOA neurons receive a moderately dense serotonergic innervation from the dorsal raphe nucleus (Vertes, 1991). Moreover, in vivo studies have shown that local application of 5-HT or selective 5-HT agonists to the MPOA inhibits or facilitates male sexual behavior in rats (Fernandez-Guasti et al, 1992; Verma et al, 1989). These observations raise the possibility that 5 -HT released from the dorsal raphe nuclei may differentially affect male sexual behavior by interacting with different 5-HT receptor subtypes in the MPOA. The results of the present study may provide information regarding the mechanism and 5-HT receptor subtypes underlying raphe modulation of MPOA neuron activity. For example, 5-HT may activate or inhibit synaptic influence to MPOA neurons by modulating presynaptic release of excitatory and inhibitory transmitters. A presynaptic action of 5-HT implies that the fibers containing 5-HT contribute to axo-axonic synapses on glutamatergic and GABAergic nerve terminals in the MPOA (Malinina et al, 2005). Our findings are consistent with earlier reports of serotonergic suppression of glutamatergic and GABAergic transmission via presynaptic $5-\mathrm{HT}_{1 \mathrm{~A} / \mathrm{B}}$ receptors in brain areas such as the amygdala (Cheng et al, 1998; Koyama et al, 1999), nucleus accumbens (Muramatsu et al, 1998), and entorhinal cortex (Schmitz et al, 1998). Our results are also consistent with and can show some explainatory clues to the results of a previous in vivo study indicating that 5-HT can facilitate and inhibit sexual behavior according to the receptor subtypes (Fernandez-Guasti et al, 1992). However, some in vivo studies have revealed that the effect of $5-\mathrm{HT}$ on the
MPOA is generally inhibitory to sexual behavior (Gorzalka et al, 1990; Hull et al, 2004; Zajecka et al, 1991). Thus, modulatory effects of 5-HT on synaptic transmission may be generally inhibitory to neural activity in the MPOA. In addition, we previously observed that 5-HT hyperpolarizes and inhibits MPOA neuronal excitability via activation of $5-\mathrm{HT}_{1 \mathrm{~A}}$ receptors (unpublished data). However, factors such as proximity between the release sites and different 5-HT receptors and the concentration of $5-\mathrm{HT}$ attainable at different receptor sites may dictate whether 5-HT has a predominantly postsynaptic or presynaptic site of action.

Although the findings of the present study were mostly consistent with the previous in vivo studies, the animals used in the present study were 10- to 15-day old. It is possible that the young animals might be sexually immature and that the physiology of young animals might not be same to that of sexually mature animals. To rule out the possibility, the action mechanism of 5-HT on MPOA neurons with synaptic boutons of adult rat should be performed.

\section{ACKNOWLEDGEMENTS}

This study was supported by the Seoul R\&D Program (10524), the Brain Korea 21 Project in 2006, and the Korea Science \& Engineering Foundation (KOSEF) grants funded by the Korea government (MOST) (nos. R13-2002-02001003-0 and R01-2005-000-10359-0).

\section{REFERENCES}

Akaike N, Harata N (1994). Nystatin perforated patch recording and its applications to analyses of intracellular mechanisms. Jpn J Physiol 44: 433-473.

Akaike N, Moorhouse AJ (2003). Techniques: applications of the nerve-bouton preparation in neuropharmacology. Trends Pharmacol Sci 24: 44-47.

Bijak M, Misgeld U (1997). Effects of serotonin through serotonin $1 \mathrm{~A}$ and 4 receptors on inhibition in the guinea-pig dendate gyrus in vitro. Neuroscience 78: 1017-1026.

Bobker DH, Williams JT (1989). Serotonin agonist inhibit synaptic potentials in the rat locus coeruleus in vitro via 5-hydroxytryptamine $_{1 \mathrm{~A}}$ and 5-hydroxytryptamine ${ }_{1 \mathrm{~B}}$ receptors. J Pharmac Exp Ther 250: 37-43.

Boschert U, Amara DA, Segu L, Hen R (1994). The mouse 5 -htdroxytryptamine ${ }_{1 \mathrm{~B}}$ receptor is localized predominately on axon terminals. Neuroscience 58: 167-182.

Bouron A (2001). Modulation of spontaneous quantal release of neurotransmitters in the hippocampus. Prog Neurobiol 63: 613-635.

Capogna M, Gahwiler BH, Thompson SM (1995). Presynaptic enhancement of inhibitory synaptic transmission by pretein kinase $\mathrm{A}$ and $\mathrm{C}$ in the rat hippocampus in vitro. J Neurosci 15: 1249-1260.

Chavez-Noriega LE, Stevens CF (1994). Increased transmitter release at excitatory synapse produced by direct activation of adenylate cyclase in rat hippocampal slices. J Neurosci 14: 310-317.

Chen C, Regehr WG (1997). The mechanism of cAMP-mediated enhancement at a cerebellar synapse. J Neurosci 17: 8687-8694.

Cheng LL, Wang SJ, Gean PW (1998). Serotonin depresses excitatory synaptic transmission and depolarization-evoked $\mathrm{Ca}^{2+}$ influx in rat basolateral amygdale via $5-\mathrm{HT}_{1 \mathrm{~A}}$ receptors. Eur J Neurosci 10: 2163-2172. 
Dumuis A, Sebben M, Bockaert J (1988). Pharmacology of 5-hydroxytryptamine-1A receptors which inhibit cAMP production in hippocampal and cortical neurons in primary culture. Mol Pharmacol 33: 178-186.

Fernandez-Guasti A, Escalante AL, Ahlenius S, Hillegaart V, Larsson K (1992). Stimulation of $5-\mathrm{HT}_{1 \mathrm{~A}}$ and $5-\mathrm{HT}_{1 \mathrm{~B}}$ receptors in brain regions and its effects on male rat sexual behavior. Eur $J$ Pharmacol 210: 121-129.

Gorzalka BB, Mendelson SC, Watson NV (1990). Serotonin receptor subtypes and sexual behavior. Ann NY Acad Sci 600: 435-446.

Greengard P, Valtorta F, Czernik AJ, Benfenanti F (1993). Synaptic vesicle phosphoproteins and regulation of synaptic function. Science 259: 780-785.

Hahm ET, Lee JJ, Min BI, Cho YW (2004). Opioid inhibition of GABAergic neurotransmission in mechanically isolated rat periaqueductal gray neurons. Neurosci Res 50: 343-354.

Hamill OP, Marty A, Neher E, Sakmann B, Sigworth FJ (1981). Improved patch-clamp techniques for high resolution current recording from cells and cell-free membrane patches. Pflügers Arch 391: 85-100.

Hoyer D, Martin G (1997). 5-HT receptor classification and nomenclature: towards a harmonization with the human genome. Neuropharmacology 36: 419-428.

Hull EM, Muschamp JW, Sato S (2004). Dopamine and serotonin: influences on male sexual behavior. Physiol Behav 83: 291-308.

Jacobs BL, Azmitia EC (1992). Structure and function of the brain serotonin system. Physiol Rev 72: 165-229.

Jeong HJ, Han SH, Min BI, Cho YW (2001). 5- $\mathrm{HT}_{1 \mathrm{~A}}$ receptormediated activation of G-protein-gated inwardly rectifying $\mathrm{K}^{+}$ current in rat periaqueductal gray neurons. Neuropharmacology 41: $175-185$.

Johnson SW, Mercuri NB, North RA (1992). 5-Hydroxytryptami$n_{1 b}$ receptors block the $G_{A B A}$ synaptic potential in rat dopamine neurons. J Neurosci 12: 2000-2006.

Karlsson U, Sundgren AK, Näsström J, Johansson S (1997a). Glutamate-evoked currents in acutely dissociated neurons from the rat medial preoptic nucleus. Brain Res 759: 270-276.

Karlsson U, Haage D, Johansson S (1997b). Currents evoked by GABA and glycine in acutely dissociated neurons from the rat medial preoptic nucleus. Brain Res 770: 256-260.

Kasai H, Petersen OH (1994). Spatial dynamics of second messengers: $\mathrm{IP}_{3}$ and cAMP as long-range and associative messengers. Trends Neurosci 17: 95-101.

Katayama J, Yakushiji T, Akaike N (1997). Characterization of the $\mathrm{K}^{+}$current mediated by $5-\mathrm{HT}_{1 \mathrm{~A}}$ receptor in the acutely dissociated rat dorsal raphe neurons. Brain Res 745: 283-292.

Klaric JS, Hendricks SE (1986). Effects of two-stage lesions of the medial preoptic area on sexual behavior of male rats. Physiol Behav 37: 539-542.

Koyama S, Kubo C, Rhee JS, Akaike N (1999). Presynaptic serotonergic inhibition of GABAergic synaptic transmission in mechanically dissociated rat basolateral amygdala neurons. J Physiol 518: 525-538.

Malinina E, Druzin M, Johansson S (2005). Fast neurotransmission in the rat medial preoptic nucleus. Brain Res 1040: 157-168.

Malsbury CW (1971). Facilitation of male rat copulatory behavior by electrical stimulation of the medial preoptic area. Physiol Behav 7: 797-805.

Maroteaux L, Saudou F, Amlaiky N, Boschert U, Plassat JL, Hen R (1992). Mouse 5-HT1B serotonin receptor: cloning, functional expression, and localization in motor control centers. Proc Natl Acad Sci USA 89: 3020-3024.

Meisel RL, Sachs BD (1994). The physiology of male sexual behavior. In: Knobil E, Neill JD (eds). Physiology of Reproduction. Raven Press: New York. pp 3-106.

Mooney RD, Shi MY, Rhoades RW (1994). Modulation of retinotectal transmission by presynaptic 5-HT1B receptors in the superior colliculus of the adult hamster. J Neurophysiol 72: 3-13.

Muramatsu M, Lapiz MDS, Tanaka E, Grenhoff J (1998). Serotonin inhibits synaptic glutamate currents in rat nucleus accumbens neurons via presynaptic 5- $\mathrm{HT}_{1 \mathrm{~B}}$ receptors. Eur J Neurosci 10: 2371-2379.

Ng GY, George SR, Zasrawny RL, Caron M, Bouvier M, Denis M et al (1993). Human serotonin 1B receptor expression in Sf9 cells: phosphorylation, palmitoylation, and adenylyl cyclase inhibition. Biochemistry 32: 11727-11733.

Oh U, Ho YK, Kim D (1995). Modulation of the serotonin-activated $\mathrm{K}^{+}$channel by $\mathrm{G}$ protein subunits and nucleotides in rat hippocampal neurons. J Membrane Biol 147: 241-253.

Pan H, Galligan JJ (1994). 5- $\mathrm{HT}_{1 \mathrm{~A}}$ and $5-\mathrm{HT}_{4}$ receptors mediate inhibition and facilitation of fast synaptic transmission in enteric neurons. Am J Physiol 266: G230-G238.

Paredes RG, Tzschentke T, Nakach N (1998). Lesions of the medial preoptic area/anterior hypothalamus (MPOA/AH) modify partner preference in male rats. Brain Res 813: 1-8.

Pazos A, Palacios JM (1985). Quantitative autoradiographic mapping of serotonin receptors in the rat brain. I. Serononin-1 receptors. Brain Res 346: 205-230.

Penington NJ, Kelly JS, Fox AP (1993). Whole-cell recordings of inwardly rectifying $\mathrm{K}^{+}$currents activated by $5-\mathrm{HT}_{1 \mathrm{~A}}$ receptors on dorsal raphe neurones of the adult rat. J Physiol 469: 387-405.

Raiteri M, Maura G, Bonanno G, Pittaluga A (1986). Differential pharmacology and function of two $5-\mathrm{HT}_{1}$ receptors modulating transmitter release in rat cerebellum. J Pharmacol Exp Ther 237: 644-648.

Rhee JS, Ishibashi H, Akaike N (1996). Serotonin modulates highvoltage-activated $\mathrm{Ca}^{2+}$ channels in rat ventromedial hypothalamic neurons. Neuropharmacology 35: 1093-1100.

Rodriguez-Manzo G, Pellicer F, Larsson K, Fernandez-Guasti A (2000). Stimulation of the medial preoptic area facilitates sexual behavior but does not reverse sexual satiation. Behav Neurosci 114: 553-560.

Scanziani M, Capogna M, Gahwiler BH, Thompson SM (1992). Presynaptic inhibition of miniature excitatory synaptic current by baclofen and adenosine in the hippocampus. Neuron 9: 919-927.

Schmitz D, Empson RM, Heinemann U (1995). Serotonin and 8-OH-DPAT reduce excitatory transmission in rat hippocampal area CA1 via reduction in presumed presynaptic $\mathrm{Ca}^{2+}$ entry. Brain Res 701: 249-254.

Schmitz D, Gloveli T, Empson RM, Draguhn A, Heinemann U (1998). Serotonin reduces synaptic excitation in the superficial medial entorhinal cortex of the rat via a presynaptic mechanism. J Physiol 508: 119-129.

Simerly RB, Gorski RA, Swanson LW (1986). Neurotransmitter specificity of cells and fibers in the medial preoptic nucleus: an immunohistochemical study in the rat. J Comp Neurol 246: 343-363.

Simerly RB, Swanson LW (1986). The organization of neuronal inputs to the medial preoptic nucleus of the rat. J Comp Neurol 246: 312-342.

Simerly RB, Swanson LW (1988). Projections of the medial preoptic nucleus: a Phaseolus vulgaris leucoagglutinin anterograde tract-tracing study in the rat. J Comp Neurol 270: 209-242.

Singer JH, Bellingham MC, Berger AJ (1996). Presynaptic inhibition of glutamatergic synaptic transmission to rat motoneurons by serotonin. J Neurophysiol 76: 799-807.

Swanson LW, Mogenson GJ (1981). Neural mechanism for the functional coupling of autonomic, endocrine and somatomotor responses in adaptive behaviors. Brain Res Rev 3: 1-34.

Tanaka E, North RA (1993). Action of 5-htdroxytryptamine on neurons of the rat cingulate cortex. J Neurophysiol 69: 1749-1757.

Thompson SM, Capogna M, Scanziani M (1993). Presynaptic inhibition in the hippocampus. Trends Neurosci 16: 222-227. 
Trudeau LE, Emery DG, Haydon PG (1996). Direct modulation of the secretory machinery underlies PKA-dependent synaptic facilitation in hippocampal neurons. Neuron 17: 789-797.

Umemiya M, Berger AJ (1995). Presynaptic inhibition by serotonin of glycinergic inhibitory synaptic currents in the rat brainstem. J Neurophysiol 73: 1192-1201.

van Gemert M, Miller M, Carey RJ, Moses AM (1975). Polyuria and impaired $\mathrm{ADH}$ release following medial preoptic lesioning in the rat. Am J Physiol 228: 1293-1297.

Verma S, Chhina GS, Mohan KV, Singh B (1989). Inhibition of male sexual behavior by serotonin application in the medial preoptic area. Physiol Behav 46: 327-330.
Vertes RP (1991). A PHA-L analysis of ascending projections of the dorsal raphe nucleus in the rat. J Comp Neurol 313: 643-668.

Wu LG, Saggau P (1994). Pharmacological identification of two types of presynaptic voltage-dependent calcium channels at CA3-CA1 synapses of the hippocampus. J Neurosci 14: 5613-5622.

Wu SY, Wang MY, Dun NJ (1991). Serotonin via presynaptic $5-\mathrm{HT}_{1}$ receptors attenuates synaptic transmission to immature rat motoneurons in vitro. Brain Res 554: 111-121.

Zajecka J, Fawcett J, Schaff M, Jeffriess H, Guy C (1991). The role of serotonin in sexual dysfunction: fluoxetine-associated orgasm dysfunction. J Clin Psychiatry 52: 66-68. 